University at Buffalo School of Law

Digital Commons @ University at Buffalo School of Law

4-1-2018

\title{
Unforeseen Land Uses: The Effect of Marijuana Legalization on Land Conservation Programs
}

Jessica Owley

University of Miami School of Law

Follow this and additional works at: https://digitalcommons.law.buffalo.edu/journal_articles

Part of the Environmental Law Commons, and the Land Use Law Commons

\section{Recommended Citation}

Jessica Owley, Unforeseen Land Uses: The Effect of Marijuana Legalization on Land Conservation Programs, 51 U.C. Davis L. Rev. 1673 (2018).

Available at: https://digitalcommons.law.buffalo.edu/journal_articles/916

\section{C. ${ }_{\text {COPYRIGHT }}^{\text {N }}$}

This Article is brought to you for free and open access by the Faculty Scholarship at Digital Commons @ University at Buffalo School of Law. It has been accepted for inclusion in Journal Articles by an authorized administrator of Digital Commons @ University at Buffalo School of Law. For more information, please contact lawscholar@buffalo.edu. 


\title{
Unforeseen Land Uses: The Effect of Marijuana Legalization on Land Conservation Programs
}

\author{
Jessica Owley*
}

This Article explores the tension between land conservation and marijuana cultivation in the context of legalization. The legalization of marijuana has the potential to shift the locations of marijuana cultivation. Where cultivation need no longer be surreptitious and clandestine, growers may begin to explore sanctioned growing sites and methods. Thus, the shift to legalization may be accompanied by environmental and landuse implications. Investigating commercial-scale marijuana cultivation, this Article details how, in some ways, legalization can reduce environmental impacts of marijuana cultivation while also examining tricky issues regarding tensions between protected lands and marijuana cultivation. If we treat cultivation of marijuana the same as we treat cultivation of other agricultural crops, we gain stricter regulation of the growing process, including limits on pesticide usage, water pollution, wetland conversion, air pollution, and local land-use laws. Thus, legalization of marijuana should yield environmental benefits. And yet the story is, of course, more complicated than that. The strange status of marijuana as both a federally impermissible use and a stigmatized crop

\footnotetext{
* Copyright @ 2018 Jessica Owley. Professor of Law, SUNY Buffalo Law School; Profesora Visitante, Universidad Pontificia - Comillas (ICADE). This piece is based on a presentation at Texas A\&M Law School in 2015 examining the implications of marijuana legalization on property law. Many thanks to the organizers and participants of that symposium as well as Justin Simard and Ryan Stoa who provided helpful feedback and discussion in the development of this piece. Faculty at the University of Denver helped me strengthen this piece through pointed questions and conversation, particularly Sam Kamin. Sam Schuchat of the California State Coastal Conservancy was helpful in understanding the California context in particular. Alex Kreit of the Thomas Jefferson School of Law improved the Article's conception of the interaction between federal and state drug laws. Lauren Ardonetto provided valuable research assistance and contributed significantly to the section describing state and federal marijuana laws.
} 
suggests that it will not fall under the same legal regimes as other agricultural products. In the realm of protected agricultural and conservation lands, a particular concern arises for land trusts grappling with proposals for marijuana cultivation. Where landowners receive federal tax benefits or land trusts rely upon federal laws for funding and legitimacy, the decision to grow marijuana on the land could have significant consequences. The Article reaches two main conclusions. First, in the absence of federal regulations, subnational governments should create and implement environmental and land-use regulations governing the cultivation of marijuana to ensure that legal grows do not continue the harmful practices involved with black market marijuana. Second, land trusts and agricultural protection organizations should not become involved with marijuana cultivation in any form while it remains illegal at the federal level. To do so puts both the land and their operations at risk.

\section{TABLE OF CONTENTS}

INTRODUCTION

I. ILLEGAL MARIJUANA CULTIVATION ..................................... 1677

A. Cultivation on Public Lands........................................ 1677

B. Cultivation on Private Lands ........................................ 1686

II. LEGAL MARIJUANA CUlTIVATION ......................................... 1692

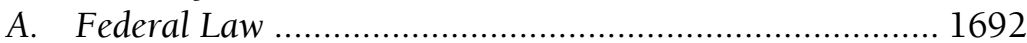

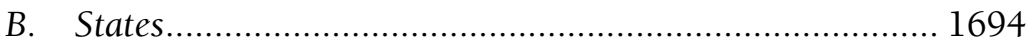

III. AGRICULTURAL AND CONSERVED LANDS AS MARIJUANA

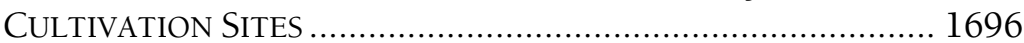

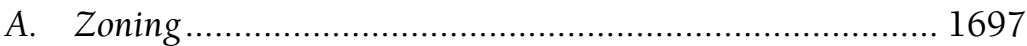

B. Farm Subsidies, Programs, and Tax Breaks ................... 1704

C. Conservation Easements ............................................... 1705

D. Environmental Protection Laws ................................... 1711

DISCUSSION AND CONCLUSION.................................................... 1713 


\section{INTRODUCTION}

The legalization of marijuana has shifted some of the locations of marijuana cultivation and with that shift comes environmental and land-use implications. Investigating commercial-scale marijuana cultivation, this Article details how, in some ways, legalization can reduce environmental impacts of growing marijuana while also raising tricky issues regarding tensions between protected lands and marijuana cultivation. Legalization of marijuana has brought some of its production out of the federal forests and individuals' closets and into more regulated agricultural production. ${ }^{1}$ In some ways, the legitimization of the process makes it less likely to be environmentally destructive. If we treat cultivation of marijuana the same as we treat cultivation of other agricultural crops, we gain stricter regulation of the growing process, including limits on pesticide usage, water pollution, wetland conversion, and air pollution. Marijuana can even be an attractive crop for soil health - a desirable rotation crop in combination with more nutrient-depleting crops. ${ }^{2}$ Thus, it appears that legalization of marijuana yields environmental benefits. And yet the story is, of course, more complicated than that. The strange status of marijuana as both a federally impermissible use and a stigmatized crop suggest that it will not fall under the same legal regimes as other agricultural products.

One recent conundrum arising with the legalization of marijuana is whether it can be grown on lands encumbered by conservation easements or other environmental or agricultural protections, such as zoning codes or favored tax status. At first glance, one might assume that where marijuana is legal, the cultivation of it should follow rules similar to other agricultural crops. Yet, the protections placed upon agricultural lands have rarely contemplated such use. Moreover, often

1 See John Schroyer, The Changing Face of Cannabis Cultivation, Marijuana Bus. MaG. (Nov. 2015), https://mjbizmagazine.com/the-changing-face-of-cannabis-cultivation.

2 See, e.g., Stephan Piotrowski \& Michael Carus, Nova Inst., Ecological Benefits of Hemp AND Flax Cultivation AND Products 1 (2011), http://eiha.org/media/2014/10/Ecological-benefits-of-hemp-and-flax-cultivation-andproducts-2011.pdf (asserting, inter alia, that the deep root system of hemp plants helps create a healthy soil structure); Michael Cheng, Benefits of Using Cannabis as a Rotation Crop in Farming, MAssRoots (Apr. 17, 2017), https://www. massroots.com/news/cannabis-farming-rotation-crop (describing studies that found cannabis plants may help detoxify the soil and increase crop yields when used in rotation with other crops); Dan Mitchell, Why Legalized Hemp Will Not Be a Miracle Crop, MOD. FARMER (Oct. 17, 2013), http://modernfarmer.com/2013/10/legalindustrial-hemp-wont-matter (explaining that hemp plants can suppress weeds and loosen soils but also pointing out the high water usage). 
such protections have federal underpinnings in funding or tax incentives. And despite legalization of marijuana at the state level, it remains a Schedule I narcotic under federal law. ${ }^{3}$ The conjunction of federal tax benefits or land conservation funding and marijuana cultivation seems rocky terrain.

Also unclear is the operation of environmental regulations and agricultural promotion laws on marijuana cultivation. Federal programs protect the nation's waterways, air, and biodiversity. They operate based on prohibitions on pollution and habitat conversion combined with a permitting system facilitating those activities. Marijuana producers operate outside of these federal permitting programs. In the wake of federal protections, states have developed environmental protection and permitting programs of their own. Yet, not all states have clarified which rules and programs will apply to marijuana farms. Environmental laws written without contemplation of issues related to marijuana cultivation leave uncertainty regarding the potential environmental impacts of the activity.

This Article explores the tension between land conservation and marijuana cultivation in the context of legalization. Part I of this Article briefly examines the land-use and environmental impacts of illegal marijuana cultivation as a precursor to understanding the potential changes brought by legalization. It does so in two parts. Section I.A. examines the illegal cultivation that occurred (and still occurs) on public lands while section I.B. examines some of the environmental implications of illegal cultivation on private lands. Thereafter, the Article proceeds in Part II to explore the implications of legal cultivation, recounting some of the potential environmental impacts and benefits from the literature. These impacts serve as a backdrop for considering the challenge of siting marijuana farms on either traditional agricultural land or protected conservation lands, discussed in section III.

While marijuana cultivation is a special case, it also highlights a concern generally of trying to determine land-use rules where underlying programs and protections did not contemplate the use at

3 In Spring 2016, the Drug Enforcement Agency ("DEA") announced its intention to consider rescheduling marijuana. See, e.g., Tom Huddleston, Jr., The DEA Will Soon Decide Whether It Will Reschedule Marijuana, ForTunE (Apr. 6, 2016), http://fortune.com/2016/04/06/dea-decision-marijuana-reschedule (discussing the DEA's announcement that it might consider rescheduling marijuana and what the implications of that decision might be). In August 2016, the DEA announced that it would not begin proceedings to reschedule marijuana. Denial of Petition to Initiate Proceedings to Reschedule Marijuana, 81 Fed. Reg. 53,688 (Aug. 12, 2016). 
the time of policy or contract formation. Particularly in the case of perpetual protections like conservation easements, users and interpreters of these agreements must carve a path for working with unforeseen land uses. The path should be a cautious one. Generally, anything not specifically prohibited in a property restriction is left in the power of the landowner, but this may be risky for conservationists and communities. Conservationists should be wary of promoting marijuana farming where the implications of federal laws concerning both the cultivator and involved environmental organizations are hazy and the potential repercussions severe.

\section{ILlEGal MARIJUANA CUlTivation}

To understand the implications of legal marijuana cultivation, one needs a full picture of the contrasting environmental impacts of illegal marijuana cultivation. This section provides that picture. This Article explores the impacts on conservation and agricultural lands, thus focusing on outdoor marijuana cultivation. This admittedly glosses over indoor growing of the crop, which has always occurred at substantial levels but in a more diffuse manner. ${ }^{4}$ The environmental impacts of the two locations of cultivation differ in many ways. ${ }^{5}$ In considering illegal outdoor cultivation, this section first examines where the cultivation occurs on public lands before turning to private lands.

\section{A. Cultivation on Public Lands}

As marijuana cultivation remains illegal under federal law, growth on federal lands has been and continues to be illegal. Even if the crop itself were not an illegal substance, the activity of trespassing on public lands to cultivate it is clearly against the law. Illicit marijuana growers have long used protected areas as locations of crop

4 This may be changing as large indoor growing centers emerge. See, e.g., Ephrat Livni, A Cannabis-Business Park Covering 1 Million Square Feet is Coming to Massachusetts, QuARTZ (Dec. 28, 2016), https://qz.com/872938/the-biggest-marijuana-grow-facility-in-theus-isnt-where-you-think-it-would-be (describing the Massachusetts project along with a few other indoor growing operations and the trend towards larger facilities); Our Projects, AMERICANN, http://americann.co/projects (last visited Nov. 12, 2017) (describing multiple projects, including a proposed two million square foot cannabis business park in Massachusetts).

5 For a detailed discussion of environmental impacts from both legal and illegal indoor marijuana, see Gina S. Warren, Regulating Pot to Save the Polar Bear: Energy and Climate Impacts of the Marijuana Industry, 40 COLUM. J. ENVTL. L. 385, 402-06 (2015). 
production. Indeed, the national forests in Mendocino County, California, have a reputation as being dangerous places to hike or explore because of the prevalence of criminal growers from Latin America and closer to home conducting marijuana growing operations. ${ }^{6}$ Partially because of the sites selected and partially because of the illicit nature of the operations, marijuana cultivation on federal lands has had many negative environmental consequences.

Illegal cultivation occurs on federal lands governed by the Bureau of Land Management, ${ }^{7}$ the U.S. Forest Service, ${ }^{8}$ the Fish and Wildlife

6 See, e.g., Mexican Pot Gangs Pollute National Parks, CBS News (Oct. 11, 2008), http://www.cbsnews.com/news/mexican-pot-gangs-pollute-national-parks-11-10-

2008. This is well documented and also based on my personal experience. When on a camping trip in Mendocino in 2001, I was given explicit instructions by local residents of trails and areas of the forest to avoid. In 2011, the Federal Government launched "Operation Full Court Press" and cleared out 632,000 plants from 93 total grow sites across five counties in California. David Christy, Operation Full Court Press: Reclaiming Public Lands, BurEau LAND MGMT. (Aug. 10, 2011), https://web.archive.org/ web/20120114213314/http://www.blm.gov/ca/st/en/info/newsbytes/2011/493xtra_fullc ourtpress_marij.html. While the operation was somewhat effective, federal lands are still used to grow marijuana illegally throughout California and elsewhere. Mark Mallery, Marijuana National Forest: Encroachment on California Public Lands for Cannabis Cultivation, 23 Berkeley Undergraduate J., no. 2, 2011, at 4; Chris Roberts, Cartels Abandon National Forest in Mendocino County, SF WeEkLy (Sept. 10, 2014), http://www.sfweekly.com/thesnitch/2014/09/10/cartels-abandon-national-forest-inmendocino-county.

7 Exploring the Problem of Domestic Marijuana Cultivation: Hearing Before U.S. Senate Caucus on International Narcotics Control, 112th Cong. (2012) (statement of Kim Thorsen, Deputy Assistant Secretary, Law Enforcement, Security and Emergency Management), https://www.doi.gov/ocl/hearings/112/MarijuanaCultivation_120711 (describing illegal cultivation on Bureau of Land Management land and other public lands). For a more recent example, see Press Release, U.S. Attorney's Office for the Dist. of Colo., BLM Rangers Discover Two Large Marijuana Grows (Oct. 5, 2015), https://www.justice.gov/usao-co/pr/blm-rangers-discover-two-large-marijuana-grows [hereinafter U.S. Attorney Press Release BLM].

8 See, e.g., Marijuana Cultivation and the Environmental Impacts on Public Lands: Public Hearing Before the U.S. Sentencing Comm'n, 113th Cong. (2013) (statement of Chris Boehm, Assistant Director, Law Enforcement and Investigations, Forest Service, U.S. Department of Agriculture), http://www.ussc.gov/sites/default/files/pdf/amendment-process/publichearings-and-meetings/20140313/Testimony_Boehm.pdf [hereinafter Boehm Testimony] (describing illegal growing operations in the National Forest system). In 2011, the U.S. Forest Service estimated that sixty-seven national forests had become home to illegal marijuana growth. Exploring the Problem of Domestic Marijuana Cultivation: Hearing Before U.S. Senate Caucus on International Narcotics Control, 112th Cong. 4 (2012) (statement of David Ferrell, Director, Law Enforcement and Investigations, Forest Service, U.S. Department of Agriculture), http://www.fs.fed.us/sites/default/files/legacy_files/media/ types/testimony/SINC_12-07-2011_Testimony.pdf. The Forest Service estimated that in 2014, seventy-three national forests across twenty-two states were home to illegal marijuana cultivation sites. Boehm Testimony, supra note 8. More than 6,000 illegal 
Service, the Bureau of Indian Affairs, the Bureau of Reclamation, ${ }^{9}$ and the National Park Service. ${ }^{10}$ It even happens in the most popular and visited of our public lands, including Yosemite National Park. In 2009, Yosemite Chief Ranger Steve Shackelton estimated the park rangers in Yosemite handled over 5,000 marijuana cultivation cases a year. ${ }^{11} \mathrm{He}$ complained that marijuana enforcement took rangers from other duties, including protecting the ecological and scenic amenities of the park. ${ }^{12}$ Shackelton described the problem as "an unprecedented crisis," explaining that illegal marijuana cultivation (sometimes called trespass marijuana, trespass grows, or guerilla grows) ${ }^{13}$ "has noticeably affected the water quality, animal life, and health and safety of the public" in the Park. ${ }^{14}$

cultivation sites were raided in national forests from 2005 to 2014. Katie Campbell \& Dom DiFurio, Growing Marijuana Industry Raises Environmental Concerns, WeEd RUSH (Aug. 15, 2015), http://weedrush.news21.com/growing-marijuana-industry-raises-environmentalconcerns. Ninety percent of these sites are in California. Id.

9 Marijuana on Public and Tribal Lands, Off. Nat'l Drug Control Pol'y, https://web.archive.org/web/20170117133720/https://www.whitehouse.gov/ondcp/ marijuana-on-public-lands (last visited Jan. 17, 2017). For a discussion of how the Bureau of Reclamation is managing water resources related to marijuana cultivation, see Rob Hotakainen, No Irrigation Water for Marijuana Crops, Feds Rule, McClatchy WASH. BUREAU (May 20, 2014), http://www.mcclatchydc.com/news/politicsgovernment/article24767869.html.

10 See Jessica Intrator et al., Student Review of Selected Panels at the California State Bar's 2009 Environmental Law Conference at Yosemite, 36 ECOlOGY L. CURRENTS 227, 227-28 (2009), http://elq.typepad.com/currents/2009/13/currents36-13-yosemite-20091201.pdf (describing problems in Yosemite National Park); Elyce Kirchner et al., Poisoned Parks: Illegal Marijuana Growers Leave National Parks Trashed, Animals Dead, NBC BAY AREA (Nov. 1, 2013), http://www.nbcbayarea.com/news/local/IllegalMarijuana-Growers-National-Parks-Trashed-Animals-Toxic-229943491.html.

11 Intrator et al., supra note 10, at 228.

12 See id. at 227.

13 See, e.g., Josh Harkinson, The Landscape-Scarring, Energy Sucking, Wildlife-Killing Reality of Pot Farming, Mother JONES (March/April 2014) (using the term "trespass grows"); Melati Kaye, Burgeoning Marijuana Market Prompts Concerns About Crop's Environmental Impact, SCI. AM. (Feb. 2, 2017), https://www.scientificamerican. com/article/burgeoning-marijuana-market-prompts-concerns-about-crop-rsquo-senvironmental-impact (using terms "trespass grows" and "guerilla grows"); Piper McDaniel, The Forest Service's Battle Against Illegal Marijuana Farms, High CounTry News (Oct. 31, 2017), http://www.hcn.org/articles/the-forest-services-battle-againstillegal-marijuana-farms (using the term "trespass marijuana" and "rogue marijuana grow"); Michael Polson, Land and Law in Marijuana Country: Clean Capital, Dirty Money, and the Drug War's Rentier Nexus, 36 Pol. \& Legal Anthropology ReV. 215, 221 (2013) (using the term "guerilla growers"); Warren, supra note 5, at 406-07 (referring to "trespass operations").

14 Intrator et al., supra note 10, at 228. 
While illegal federal grows have predominately been located on public lands in California, ${ }^{15}$ the problem of environmentally destructive trespass grows spans across public lands in over twenty states. ${ }^{16}$ Large trespass grows have been discovered in Oregon, ${ }^{17}$ Wisconsin, ${ }^{18}$ and even as far east as Kentucky. ${ }^{19}$ More recently the problem of illegal grows has begun to plague Colorado, likely the result of California's long drought-ridden landscape and several bad fire seasons. ${ }^{20}$ In 2014, the Forest Service reported that since 2008 it had found thirty-six illegal grow operations and seized more than 100,000 plants on federal land in Colorado. ${ }^{21}$ Although Colorado has legalized marijuana, such grows are not in compliance with the state's framework for legal marijuana production and are thus illegal under both federal and state law.22 In an October 2015 statement, John Walsh, the U.S. Attorney for the District of Colorado, explained that "Colorado has seen an explosion in the number and size of illicit marijuana grows on public land." 23 A spokesperson from within the

15 See Campbell \& DiFurio, supra note 8.

16 Boehm Testimony, supra note 8.

17 Three thousand plants were eradicated from the Willamette National Forest in central Oregon. The Register-Guard, A National Forest Pot Bust for the Record Books, Or. Pub. Broadcasting (Aug. 26, 2013), http://www.opb.org/news/article/a-nationalforest-pot-bust-for-the-record-books. Also in Oregon, another 90,000 plants were found and eradicated in the Wallowa-Whitman National Forest. Melissa Block, Marijuana Plants Discovered at National Forest, NPR: ENv'T (June 29, 2011), http:// www.npr.org/2011/06/29/137506912/marijuana-plants-discovered-at-national-park.

18 Approximately a dozen illegal grows have been found in Wisconsin, where the grows tend to be located in national forests in the northern part of the state. J.B. Van Hollen, Growing out of Business, Wis. NAT. Resources Mag. (Aug. 2013), http://dnr.wi.gov/wnrmag/2013/08/growing.htm.

19 Although to a lesser extent today, in the early 2000s Daniel Boone National Forest was a hotbed of illegal marijuana cultivation. See Nat'l Drug Intelligence Ctr., Marijuana and Methamphetamine Trafficking on Federal Lands Threat Assessment, U.S. DEP'T JUST. (Feb. 2005), https://www.justice.gov/archive/ndic/pubs10/10402/marijuan.htm.

20 See David Long, Pot: A Growing Menace on Public Lands, Four Corners FreE PRESS (Jan. 10, 2016), http://fourcornersfreepress.com/?p=2907.

21 Jennifer Kovaleski, Illegal Pot Grows Destroying Colorado's National Forests, DENVER 7 ABC (Nov. 10, 2014, 9:23 PM), http://www.thedenverchannel.com/ news/local-news/illegal-pot-grows-destroying-colorados-national-forests-us-forestservice-says.

22 For a chronicle of illegal grows on National Forest lands and Bureau of Land Management lands in Colorado, see Press Release, U.S. Attorney's Office for the Dist. of Colo., Confronting Wave of Illicit Marijuana Cultivation, Federal, State and Local Authorities Discover and Destroy Major Marijuana Grows in Locations Across Colorado (Oct. 8, 2015), https://www.justice.gov/usao-co/pr/confronting-wave-illicitmarijuana-cultivation-federal-state-and-local-authorities.

23 U.S. Attorney Press Release BLM, supra note 7. 
U.S. Attorney's Office suggested that the increase in illegal grows is, in part, due to criminals' mistaken belief that Colorado's "more liberal posture on marijuana" would make the state an ideal place to grow trespass marijuana. ${ }^{24}$

The environmental impacts of illicit marijuana cultivation on public lands are manifold. 25 To begin with, because these plantations are often in the midst of protected forest areas, planting the crops means removing the previous understory vegetation. ${ }^{26}$ Removal of native vegetation deprives the forest of important components of the ecosystem - changing the soil and water regime as well as disrupting wildlife habitat. For example, illegal growers dam streams and divert water to irrigate the crops. ${ }^{27}$ According to the U.S. Forest Service, illegal growers "frequently damage soils, cut timber, and clear vegetation to create room for their grows, creating resource damage and erosion problems." 28

These trespassers use fertilizers and pesticides.29 In fact, growers may use pesticides for which it would be hard to get a license from the Environmental Protection Agency (like Furadan, which is banned by the EPA). ${ }^{30}$ Studies have shown that illegal growers use excessive and sometimes illegal pesticides as well, putting the crop yield above

24 Long, supra note 20.

25 See Van Butsic \& Jacob C. Brenner, Cannabis (Cannabis sativa or C. indica) Agriculture and the Environment: A Systematic, Spatially-Explicit Survey and Potential Impacts, ENVTL. RES. LETTERS, Apr. 2016, at 1, 2, doi:10.1088/1748-9326/11/4/044023.

26 See Warren Eth, Up in Smoke: Wholesale Marijuana Cultivation Within the National Parks and Forests, and the Accompanying Extensive Environmental Damage, 16 PENN ST. ENVTL. L. REV. 451, 471-72 (2008) (describing the damage from the terracing process often used); Mourad W. Gabriel et al., Silent Forests? Rodenticides on Illegal Marijuana Crops Harm Wildlife, WildLifE PROF. 46, 49, http://www.iercecology.org/wp-content/ uploads/2013/03/Silent_Forests_by_Mourad_W._Gabriel_et_al.TWP_Spring_2013.pdf [hereinafter Silent Forests?]; Diane Toomey, The High Environmental Cost of Illicit Marijuana Cultivation, YALE ENV'T 360 (July 16, 2015), http://e360.yale.edu/feature/ the_high_environmental_cost_of_illicit_marijuana_cultivation/2895.

27 Boehm Testimony, supra note 8; see Toomey, supra note 26.

28 Campbell \& DiFurio, supra note 8.

29 See Boehm Testimony, supra note 8.

30 Furadan is a toxic pesticide made using a compound called carbamate. Frederick M. Fishel, Univ. of Fla. Inst. of Food \& Agric. SCi., Pesticide Toxicity Profile: Carbamate Pesticides PI-51 (June 2005), http://edis.ifas.ufl.edu/pdffiles/ PI/PI08800.pdf. Carbamate pesticides have been found at numerous illegal grow operations on federal lands. Boehm Testimony, supra note 8; Press Release, U.S. Attorney's Office for the E. Dist. of Cal., Case Update: Central Valley Marijuana Traffickers (Mar. 26, 2014), https://www.justice.gov/usao-edca/pr/case-update-centralvalley-marijuana-traffickers. For a description of how growers use carbamate pesticides to kill animals, see Gabriel et al., Silent Forests?, supra note 26, at 48. 
environmental protection. ${ }^{31}$ This has led the Center for Public Integrity to assert that " $[\mathrm{m}]$ any illegal growers blatantly disregard regulations intended to protect sensitive habitats and lands." 32 This chemical use can harm native plant species as well as pollute the water. ${ }^{33}$ Some of the environmental damage that is most acute at the growing sites is the result of toxic fertilizers and rat poison. ${ }^{34}$ Poison passes up through the food chain (rats to bobcats to mountain lions or eagles); poison gets into the water too. ${ }^{35}$ One biologist declared that "we will likely see the effects of their toxic chemicals in our soil and water for decades." 36 Pesticides and fertilizers hurt other flora and fauna and remain in the soil - specific problems have been noted with the California fisher - according to Mourad Gabriel of the Integral Ecology Research Center. ${ }^{37}$ Owl species are getting rodenticides in their system from consuming rats that nibbled on sprayed marijuana plants. ${ }^{38}$ Back in Yosemite National Park, Shackelton saw "off the charts" nitrate levels in the waterways and expressed concerns about the pollutant's impacts on endangered

31 See, e.g., M.W. Gabriel et al., Exposure to Rodenticides in Northern Spotted and Barred Owls on Remote Forest Lands in Northwestern California: Evidence of Food Web Contamination, 12 Avian CONSERvation \& ECOlogy 2 (2018), https://doi.org/ 10.5751/ACE-01134-130102 [hereinafter Exposure to Rodenticides]; Dave Stone, Cannabis, Pesticides and Conflicting Laws: The Dilemma for Legalized States and Implications for Public Health, 69 Reg. Toxicology \& Pharmacology 284, 285 (2014).

32 Katie Campbell \& Dom DiFurio, Growers Look for Sustainability in Resource Heavy Weed Industry, CTR. FOR PUB. INTEGRITY (Aug. 19, 2015), https://www. publicintegrity.org/2015/08/19/17868/growers-look-sustainability-resource-heavyweed-industry; Campbell \& DiFurio, supra note 8.

33 See Jennifer K. Carah et al., High Time for Conservation: Adding the Environment to the Debate on Marijuana Legalization, 65 BIOSCIENCE 822, 824 (2015), http://bioscience.oxfordjournals.org/content/early/2015/06/19/biosci.biv083.full; see also Eth, supra note 26, at 452 (describing use of toxic N-P-K fertilizer in Sequoia National Park).

34 See Eth, supra note 26, at 452; Gabriel et al., Silent Forests?, supra note 26, at 48 (noting how ERT-remediated sites were ravaged by pesticides and rat poison); Toomey, supra note 26 (describing harmful chemicals used by marijuana farmers).

35 Carah et al., supra note 33, at 824; see Gabriel et al., Exposure to Rodenticides, supra note 31 (demonstrating negative impacts on northern spotted owls).

36 Jesse Nathan, The Tragedy of Mendocino, MCSwEENEY's Q., 2010, at 4.

37 Gabriel et al., Silent Forests?, supra note 26, at 46; Craig Thompson et al., Impacts of Rodenticide and Insecticide Toxicants from Marijuana Cultivation Sites on Fisher Survival Rates in the Sierra National Forest, California, U.S. FOREST SERV. 1 (2013), http://www.fs.fed.us/psw/publications/thompson/psw_2013_thompson001.pdf (naming Mourad Gabriel as co-author).

38 Campbell \& DiFurio, supra note 8. 
species within the Park. ${ }^{39}$ He described a pathway of moving the contaminants up the food stream from truffles to squirrels to spotted owls. ${ }^{40}$

Harm to wildlife occurs through other avenues as well. Changes in soil and water regimes disrupt the wildlife relying on those resources. Growers also sometimes hunt animals like deer for food (hunting of any kind is not permitted in National Parks). ${ }^{41}$ They may also harm wildlife to deter other animals from coming near their grow sites or kill endangered species to take home as trophies. ${ }^{42}$ Illegal growers sometimes place poisons inside of tuna cans to lure and kill animals around the grow sites, and such methods have been so devastatingly effective at killing animals that local law enforcement officials refer to the poisoned tuna cans as "wildlife bombs." 43

Heavy water use is one of the biggest problems. Some environmentalists, farmers, and growers push for legalization because they want to see more control of the amount of water taken out of streams. ${ }^{44}$ A recent study by the California Department of Fish and Wildlife found that two watersheds in northern California are supplying water to 23,000 to 32,000 plants, which is likely an underestimate. ${ }^{45}$ During the ninety-day growing cycle, the plants generally use six gallons of water a day each, depleting the watershed from 138,000 to 192,000 gallons daily. ${ }^{46}$ Illegal growers are not regulated, so no one tracks their water usage. Altered stream flows lead to increased sedimentation. ${ }^{47}$ Irrigation increases erosion, which damages riparian habitats and creates problems for fish. ${ }^{48}$ As the Wildlife Land Trust explains, "[s]mall streams are dammed and the water is diverted to other drainages or used to water plants in the grows, leaving the wildlife who rely on the water in need of new

\footnotetext{
39 Intrator et al., supra note 10, at 228.

40 Id.

41 Id.; see Eth, supra note 26, at 453.

42 Intrator et al., supra note 10, at 228.

43 Gabriel et al., Silent Forests?, supra note 26, at 48.

44 See Campbell \& DiFurio, supra note 8.

45 Scott Bauer et al., Impacts of Surface Water Diversions for Marijuana Cultivation on Aquatic Habitat in Four Northwestern California Watersheds, PLoS ONE 11, 14 (Mar. 18, 2015), http://journals.plos.org/plosone/article/asset?id=10.1371\%2Fjournal.pone. 0120016.PDF; see also Butsic \& Brenner, supra note 25, at 8 (estimating 668,000 cubic meters of water usage for marijuana growing operations in sixty randomly sampled watersheds in Humboldt County, California).

46 Id. at 11.

47 Carah et al., supra note 33, at 825.

48 Intrator et al., supra note 10, at 228.
} 
resources." 49 The Office of National Drug Control Policy is said to have estimated the damage from illegal marijuana cultivation to be ten acres damaged for each acre planted. 50

There are also environmental impacts from those who plant and guard the crops. Their trails through the public land increase erosion and can further impact biodiversity. ${ }^{51}$ These individuals are not light impact campers; they are changing the landscape to suit their needs and are often leaving lots of garbage. ${ }^{52}$ There can be hundreds of pounds of trash and human waste left behind at a cultivation site, including tarps used to line illegal water holding areas, camping equipment, generators, car batteries, and propane canisters. ${ }^{53}$ In a 2011 federal operation, 335 sites were cleared out in California removing 130 tons of trash, 300 pounds of pesticide, 5 tons of fertilizer, and 260 miles of irrigation piping. ${ }^{54}$ Illegal marijuana growers and their makeshift camps in densely forested areas increase the risk of wildfires. 55

There have been several organized campaigns to eradicate marijuana production on national forest lands. ${ }^{56}$ These efforts often reveal

49 Environmental Reclamation Team, Humane SOC'y Wildife LAND TR., http://www.wildlifelandtrust.org/sanctuaries/conservation-projects/environmentalreclamation.html (last visited June 25, 2016).

50 Nat'l Drug Intelligence CtR., Domestic Cannabis Cultivation Assessment 2007, at 12 (2007), https://www.justice.gov/archive/ndic/pubs22/22486/22486p.pdf; see also Chuck Squatriglia, Pot Farms Ravaging Park Land/Big Raid in Marin County Hints at the Extent of Damaging Techniques by Growers, SFGATE (Sept. 6, 2006), http://www.sfgate.com/bayarea/article/Pot-farms-ravaging-park-land-Big-raid-in-Marin2469983.php (listing that statistic and naming the Office of National Drug Policy as the source).

51 See Carah et al., supra note 33, at 824.

52 See Eth, supra note 26, at 452, 477-78; Harkinson, supra note 13.

53 The sheer quantity of the trash left behind by illegal growers in National Forests is astonishing; in 2013 more than 118,000 pounds of trash was removed from illegal grow sites in California alone. Boehm Testimony, supra note 8.

54 Campbell \& DiFurio, supra note 8; Jennifer Welsh, Pot Growers Destroying National Forests, LIVE SCI. (Dec. 12, 2011), http://www.livescience.com/17417marijuana-growers-national-forests.html.

55 Id. at 32. For further commentary about the wildfire risks associated with illegal marijuana grows in national forests and the source of the La Brea Wildfire, see Exploring the Problem of Domestic Marijuana Cultivation: Hearing Before U.S. Senate Caucus on International Narcotics Control, 112th Cong. 5 (2011) (statement of R. Gil Kerlikowske, Director of National Drug Control Policy), http://www.drugcaucus. senate.gov/sites/default/files/ONDCP\%20testimony\%20on\%20marijuana\%2012\%2006 $\% 2011 \% 20$ final.pdf.

56 See, e.g., Christy, supra note 6 (reporting the results of one such campaign, Operation Full Court Press, which succeeded in eradicating and reclaiming ninetythree and thirty-five grow sites, respectively, in addition to removing 632,000 plants, 
intense environmental harm to the areas in question. While these efforts are mostly centered in government law enforcement entities like the U.S. Forest Service, environmental protection nonprofit organizations have also been part of the process. For example, the Wildlife Land Trust (part of the Humane Society) works to clean up trespass marijuana on federal land. ${ }^{57}$

Beyond environmental impacts, the growing of marijuana can affect the use of federal lands by recreationalists and other users as they become afraid of stumbling upon growing sites staffed by armed guards. ${ }^{58}$ In California, many illegal growing sites are operated by powerful Mexican drug cartels. ${ }^{59}$ Some of these groups moved their growing sites from Mexico to California to reduce the need to smuggle the crop over the border. ${ }^{60}$ Sites are chosen for their remoteness and ability to elude detection. ${ }^{61}$ Public safety concerns related to these

twenty-five tons of garbage, and forty miles of drip irrigation tubing); Erin Curtis, Operation Mountain Sweep Targets Illegal Marijuana Grows on Public Lands, Bureau LAND MGMT. (Aug. 2012), https://web.archive.org/web/20160929142622/https:// www.blm.gov/ca/st/en/info/newsbytes/2012/545xtra_op_mtn_sweep.html (discussing Operation Mountain Sweep, which resulted in the successful eradication of over half a million plants from public lands across several states).

57 Environmental Reclamation Team, supra note 49.

58 See Intrator et al., supra note 10, at 228; see also Mitch Moxley, Green but Not Green: How Pot Farms Trash the Environment, SLATE, http://www.slate.com/ articles/news_and_politics/uc_breakthroughs_2014/2014/04/green_but_not_green_ how_pot_farms_trash_the_environment.html (last visited Dec. 30, 2017) (describing safety concerns for those doing environmental research in the national forests).

59 Mallery, supra note 6, at 4; Squatriglia, supra note 50 (stating that federal officials estimate that eighty percent of marijuana cultivation on federal land is by Mexican cartels). A rancher from Mendocino County explained that Mendocino National Forest should be renamed "Cartel National Forest," due to the prevalence of drug growing gangs in the wilderness. Damon Tabor, Weed Whackers, OUTSIDE ONLINE (May 3, 2012), http://www.outsideonline.com/1899186/weed-whackers. In 2011, the U.S. Attorney for Northern California, Melinda Haag, declared that "Mendocino National Forest is under attack by drug traffickers." Lisa Girion, Raids on Northern California Pot Farms Yield 101 Arrests, L.A. Times (July 31, 2011), http://articles.latimes.com/2011/jul/31/local/la-me-pot-raid-20110731. The problem has not seemed to lessen with legalization or increased enforcement actions. McDaniel, supra note 13 (explaining that Mexican cartels began growing marijuana on federal land in the early 2000s and the number and size of grows increases annually).

60 Mallery, supra note 6, at 7-8. Additionally, California soils and growing conditions are said to yield superior product. See Ben Parker Karris, Why California's Emerald Triangle Produces the Best Weed in the World, Kindland (Aug. 29, 2017), https://www.thekindland.com/products/why-californias-emerald-triangle-producesthe-best-weed-in-the-2941.

61 Mallery, supra note 6, at 10. 
grows take law enforcement time away from search and rescue efforts and other important tasks. ${ }^{62}$

In 2013, U.S. Department of Justice Deputy Attorney General James Cole issued a memorandum ("Cole Memorandum") to all U.S. attorneys providing guidance on marijuana enforcement in reaction to the legalization of the drug in several states. ${ }^{63}$ Among his stated reasons for continuing stringent enforcement was the need to prevent environmental dangers posed by marijuana production on federal lands. ${ }^{64}$

\section{B. Cultivation on Private Lands}

Illegal cultivation on private land often occurs by the landowners themselves. While these growers may not be violating trespassing rules, they are not usually complying with environmental laws. ${ }^{65}$ Marijuana can be a water and energy intensive crop and sometimes growers resort to nefarious means to obtain both resources. ${ }^{66}$

Alongside people illegally growing marijuana on their own land, trespassers cultivate on private forest and conservation land. There are examples of growers using private lands of others to grow marijuana without the landowners' knowledge (or consent of course). ${ }^{67}$ One well-documented example comes from Albion, California, on land owned by the Conservation Fund, a national organization that purchases land to protect it, usually with the goal of transferring the land to a government agency or nonprofit land trust that will steward

62 See Drug Control Program, USDA Forest SeRV. L. EnForCEMENT \& INVESTIGATIONS, http://www.fs.fed.us/lei/drug-control-program.php (last visited July 20, 2016). Mourad Gabriel, an ecologist who has researched the effects of marijuana grows on the environment and the pacific fisher, has said his time is now spent dealing with the environmental impacts of marijuana grows. Harkinson, supra note 13.

63 Memorandum from James M. Cole, Deputy Attorney Gen., U.S. Dep't of Justice, to all U.S. Attorneys, Guidance Regarding Marijuana Enforcement (Aug. 29, 2013), https://www.justice.gov/iso/opa/resources/3052013829132756857467.pdf.

64 Id. at 2.

65 Moxley, supra note 58 ("California's murky marijuana laws ... [have] created a situation in which some farmers follow regulations while others disregard them completely.").

66 See Dana Kelly, Note, Bringing the Green to Green: Would the Legalization of Marijuana in California Prevent the Environmental Destruction Caused by Illegal Farms?, 18 Hastings W.-N.W. J. ENVTL. L. \& POL'y 95, 97 (2012).

67 See, e.g., Moxley, supra note 58 ("If you have water available, if you have land that's free, that you can trespass on - I have seen grow sites throughout the landscape of California. It's prevalent everywhere."). 
the land. ${ }^{68}$ Someone from the Conservation Fund stumbled onto "a garden containing dozens of cannabis plants" and then called in the California Department of Fish and Game. ${ }^{69}$ The plants were being irrigated by pipes connected to nearby streams. California Fish and Game found campsites with heavy debris. There were five or six terraced gardens within a square mile consisting of 60 to 100 plants. ${ }^{70}$

Without active occupation by diligent landowners, conservation lands can be attractive grow sites. The growing cycle to produce a harvestable marijuana plant from a seed is approximately two to four months. ${ }^{71}$ The growing season in the United States runs generally between June and October, which may include multiple plantings and harvests. ${ }^{72}$ Meanwhile, requirements for monitoring conservation land may be nonexistent to minimal (in some cases legally required on an annual basis and some places even less frequently). ${ }^{73}$ These conservation sites then have some of the same characteristics that made remote federal wilderness so attractive: large areas, good soils, and little oversight or active use.

Another documented example of conscripting conservation land for illegal cultivation comes again out of California. In Wooster $v$. Department of Fish and Game, a landowner brought a quiet title action to establish that he owned his property free and clear of a recorded conservation easement. ${ }^{74}$ Conservation easements are a common land conservation tool for private lands. ${ }^{75}$ The landowner enters into a contract-like agreement with a government agency or a nonprofit organization known as a land trust. ${ }^{76}$ Akin to negative easements, conservation easements most often involve a landowner agreeing to

68 Conservation Acquisition, CONSERvation FUnD, http://www.conservationfund.org/ what-we-do/conservation-acquisition (last visited July 6, 2016).

69 Nathan, supra note 36.

70 Id.

71 Yael Grauer, From Seed to Weed: What Does It Take for Your Green to Grow?, CANNABIST (May 12, 2014), http://www.thecannabist.co/2014/05/12/seed-weed/11158.

72 Cannabis Cultivation Trends, NAT'L Drug InTelligence CTR., https://www. justice.gov/archive/ndic/pubs22/22486/cannabis.htm (last visited Dec. 28, 2017).

73 See A.M. Merenlender et al., Land Trusts and Conservation Easements: Who Is Conserving What for Whom?, 18 CONSERvation Biology 65, 67 (2004).

74 Wooster v. Dep't of Fish \& Game, 151 Cal. Rptr. 3d 340, 342 (Cal. Ct. App. 2012).

75 Julie Ann Gustanski, Protecting the Land: Conservation Easements, Voluntary Actions, and Private Lands, in Protecting the LAND: Conservation Easements Past, PRESENT AND FutURe 9 (Julia Ann Gustanski \& Roderick H. Squires eds., 2000).

76 See Federico Cheever \& Nancy A. McLaughlin, An Introduction to Conservation Easements in the United States: A Simple Concept and a Complicated Mosaic of Law, 1 J.L. PROP. \& SOC'Y 107, 118 (2015). 
refrain from an otherwise permissible act with the goal of yielding a conservation benefit. ${ }^{77}$ In exchange for the restriction, the landowner receives a credit for a charitable tax donation, money, or a development permit. ${ }^{78}$ Most conservation easements are perpetual. ${ }^{79}$

In 1981, the prior owners of Wooster's land entered into a conservation easement with the California Department of Fish and Game. ${ }^{80}$ The conservation easement's stated purpose was "...to preserve and protect [the property], for wildlife conservation purposes... and to prevent... degradation of fish and wildlife habitat due to residential, industrial or other uses detrimental to such purposes." 81 The landowners agreed to use the land for grazing livestock with the possibility of adding mineral exploration in the future and required the Department of Fish and Game ${ }^{82}$ to "post the property at all points of entry to inform the public that said property is a State wildlife area and that no trespassing or hunting is allowed." 83

77 Cf. Peter M. Morrisette, Conservation Easements and the Public Good: Preserving the Environment on Private Lands, 41 NAT. ResOuRCES J. 373, 408 (2001) (implying that affirmative conservation easements are easements where the landowner agrees to perform a specified duty).

78 See Jessica Owley, The Emergence of Exacted Conservation Easements, 84 NEB. L. REv. 1043, 1088 (2006); see, e.g., Bruce v. Comm'r, 101 T.C.M. (CCH) 1739, at 17 (T.C. 2011) (describing a complicated transfer of a conservation easement based on a settlement agreement). At times, conservation easements are created through court settlements, but these have not been well documented, and the prevalence of such conservation easements is unknown.

79 Three states (California, Florida, and Hawaii) require conservation easements to be perpetual. CAL. Civ. CODE § 815.2 (b) (2018); Fla. STAT. § 704.06(2) (2018), HAW. ReV. Stat. \& 198-2(b) (2013). North Dakota prohibits it. See N.D. Cent. Code § 4705-02.1 (2018). In most states, perpetuity is the default and some states have minimum terms. However, perpetuity may not always be the best option. See Jessica Owley, Changing Property in a Changing World: A Call for the End of Perpetual Conservation Easements, 30 STAN. ENVTL. L.J. 121, 142-60 (2011) (explaining that perpetual land restrictions are ill-suited to changing landscapes and changing social norms).

80 Wooster v. Dep't of Fish \& Game, 151 Cal. Rptr. 3d 340, 343 (Cal. Ct. App. 2012).

81 Id.

82 Now called the California Department of Fish and Wildlife. Kenneth R. Weiss, Name Change: California Department of Fish and Wildlife, L.A. TimES (Jan. 2, 2013), http://articles.latimes.com/2013/jan/02/science/la-sci-sn-california-department-of-fishand-wildlife-20130102.

83 Wooster, 151 Cal. Rptr. 3d at 343. It is not clear what the landowners got in exchange for this conservation easement. It may have been a donation (in which case the landowners likely received a charitable tax deduction). See Nancy A. McLaughlin, Conservation Easements: Perpetuity and Beyond, 34 ECOlOGY L.Q. 673, 675 (2007). However, the California Department of Fish and Wildlife rarely accepts donations of 
The Department of Fish and Game neglected to post the signs, and many people trespassed on the property. ${ }^{84}$ In fact, a marijuana growing operation set up shop there. ${ }^{85}$

After Wooster bought the property in 2009, he argued that the conservation easement should be canceled because, inter alia, the Department of Fish and Game had neglected to either post signs or keep out trespassers, including the marijuana growers. ${ }^{86}$ Wooster lost his case because he failed to prove that the nonperformance of posting was "a condition subsequent to requiring forfeiture of the department's interest in the property." 87 The court did allow Wooster to proceed in an action that would clarify the respective rights of the parties involved. 88

While this case is not about the marijuana plot per se, it does address issues related to illegal cultivation. As occurs on federal lands, marijuana cultivators sometimes trespass on private conservation

conservation easements, so it was more likely an exaction. See Cal. Dep't of Fish \& Wildlife, Landscape Conservation Planning, CA.GOv, https://www.wildlife.ca.gov/ Conservation/Planning (last visited Dec. 28, 2016) (explaining the mitigation and planning programs under which the Department may end up holding conservation easements). Where a conservation easement is created in exchange for a development permit, the public should be particularly wary. The judiciary also should be less likely to terminate or dissolve such conservation easements. See Jessica Owley, Exacted Conservation Easements: Emerging Concerns with Enforcement, 26 ProB. \& PrOP., no. 1, Jan.-Feb. 2012, at 51, 53; Jessica Owley, Exacting Conservation Easements in California, 21 ENVTL. L. News 3, 7 (2012). Without knowing more about the context of the conservation easement's creation, it is hard to determine what the requirements would be for monitoring or enforcing this conservation easement.

84 Wooster, 151 Cal. Rptr. 3d at 343.

85 Id.

86 Id. Wooster also argued that the Department of Fish and Game was not authorized to accept a grant of full hunting rights as the conservation easement purported to do, and that such a grant was at odds with the general purposes of the conservation easement. Id.

87 Id. Because the posting provision was one of the covenants in the conservation easement and not a condition subsequent to the existence of the conservation easement, the failure to comply with the posting requirement did not invalidate the conservation easement. Id. That is, if the posting requirement (or we can conceive of other requirements) was required as a condition of the parties initially entering into the conservation easement agreement, failure to comply with the requirement would mean that the conservation easement should never have been recorded. If, however, the posting requirement is just one of a long list of independent covenants within the agreement, then failure to comply with the obligations does not invalidate the other covenants. Presumably, it could be addressed as a breach of contract, but the remedy for the breach would not be termination of the conservation easement as Wooster sought.

$88 \mathrm{Id}$. 
lands where property owners are not vigilant or where the conditions of the property make hiding illegal cultivation possible. Some landowners purposely choose not to actively use conservation land and encourage unrestricted plant growth. ${ }^{89}$ Determining the best way to protect conservation land from illicit growing operations likely requires more diligent monitoring and inspection, something often noted as desirable for conservation lands generally..$^{90}$ But most holders only monitor once a year. ${ }^{91}$ There is a move to monitor more frequently by aerial photographs or drones, which may not detect all marijuana cultivations as with plants growing under trees or between crops. ${ }^{92}$ Where the holder is a government agency, the monitoring rules are less clear. ${ }^{93}$

89 C.f. Reed F. Noss, The Wildlands Project: Land Conservation Strategy, in EnVironmental Policy ANd Biodiversity 233, 239 (R. Edward Grumbine ed., 1994) (describing different land conservation approaches).

90 See generally Merenlender et al., supra note 73, at 70; Adena R. Rissman, Rethinking Property Rights: Comparative Analysis of Conservation Easements for Wildlife Conservation, FOUND. FOR ENVTL. CONSERVATION 1, 5-6 (2013), https://pdfs. semanticscholar.org/le3c/e8fa4c282b5480bd0b4412c5364598d9e011.pdf.

91 Elizabeth Byers \& Karin Marchetti Ponte, The Conservation Easement HANDBOOK 143 (2005); see also LAND TruSt AllianCe, Land Trust: StandardS AND PRACTICES 13 (2004), http://s3.amazonaws.com/landtrustalliance.org/LandTrustStandards Practices2004.pdf.

92 See Craig D. Ebert, Drones on the Horizon: Using New Technology to Monitor Conservation Easement Compliance, 45 REAL EsT. L.J. 6, 19, 32 (2016) (suggesting that drones may be a preferable monitoring tool because it will not lead to in-person confrontations with lawbreakers). But see Bustic \& Brenner, supra note 25 (researching marijuana grows through satellite data).

93 The case raises (but does not answer) the interesting question of which party to the conservation easement should be responsible for the actions of trespassers. Was the state supposed to prevent the marijuana cultivation or was the landowner? Should the state be responsible because it failed to post the no trespassing signs and take other actions to ensure that the conservation easement was being complied with? Or does the landowner have the responsibility to ensure that his land is used in a legal way in compliance with the terms and purposes of the conservation easement? Will the landowner be subject to asset forfeiture laws? If the state was the responsible party, it should have been diligently monitoring the land and bringing enforcement actions against the trespassers. This seems sensible in many ways as the state may be a better enforcer and have better resources at its disposal for actions against growers. Such a rule makes less sense in the more common pattern where land trusts, nongovernmental charitable organizations, hold the conservation easements. The land trust would not be in a superior position to the landowner to bring an action against the trespassing marijuana grower. A more logical approach places the responsibility to ensure conservation easement compliance than the landowner. In general, the landowner is the one who should be more familiar with the day-to-day operations of the land and have better notice of trespassers. The landowner is also in a firmer stance legally with being able to bring an enforcement action against a trespasser. Could a 
Environmental impacts of illicit marijuana cultivation on private land are similar to those we see on public land. ${ }^{94}$ For example, marijuana cultivation is water intensive and results in high levels of water diversion even in arid climates or in times of drought. ${ }^{95}$ While the exact figures are disputed, some estimates assert that marijuana plants require five to eight gallons per plant per day - twice what grapes need, for example. ${ }^{96}$ At times, the water diversion and use can create such large problems of erosion and health of water bodies that expensive restoration projects are needed. ${ }^{97}$ Streams in Mendocino run dry during the marijuana growing season - impacting Coho salmon and steelhead trout who lay their eggs in the region's waterways. ${ }^{98}$ One biologist reported seeing "dead steelhead and Coho on a regular basis

conservation easement holder bring an enforcement action against the landowner for her failure to kick marijuana growers off the land? The answer is unclear. See generally Jessica E. Jay, Enforcing Perpetual Conservation Easements Against Third-Party Violators, 32 UCLA J. ENVTL. L. \& POL'Y 80, 89 (2014). Some landowners believe that encumbering their land with a conservation easement will give them an enforcer against trespassers. That is, they restrict their land with a conservation easement that prohibits activities like ATV use or marijuana cultivation, and then they want the land trust to enforce the conservation easement against third-party trespassers. Yet, few conservation easements contain terms clarifying who is responsible for preventing incursions by third parties, and the law has yet to develop a default answer that would apply where parties fail to negotiate the term.

94 Indoor grows have their own series of problems. To begin with, they use a lot of electricity, often powered by diesel generators. See Carah et al., supra note 33, at 823; Harkinson, supra note 13. An environmental health specialist in Humboldt County noted twenty to thirty substantial petroleum spills a year at marijuana grow sites. Nathan, supra note 36. In one example, a nearby family called in to report that their water tasted funny. Authorities found an illegal underground greenhouse and that marijuana harvesters poured their waste oil directly on the ground. Id. There have also been indoor house fires from illegal growing. Id. at 5. A typical grow house uses 200 watts per square foot - about the same amount of energy necessary to power a modern data center. Campbell \& DiFurio, supra note 8. These harms suggest that legalizing marijuana cultivation so it no longer need be done in secret could also lessen some of these harms.

95 Toomey, supra note 26.

96 See Bauer et al., supra note 45, at 2; Carah et al., supra note 33, at 823; Toomey, supra note 26. See generally Cole Mellino, Thirsty (and Illegal) Pot Farms Stealing Water Amid California's Epic Drought, ECOWATCH (Dec. 16, 2015, 2:35 PM), http://www.ecowatch.com/thirsty-and-illegal-pot-farms-stealing-water-amid-californiasepic-dro-1882130296.html (stating that it takes approximately 900 gallons of water to bring an outdoor plant to harvest, and 450 gallons for a plant grown indoors).

97 See, e.g., Carah et al., supra note 33, at 825-27; Toomey, supra note 26.

98 Nathan, supra note 36; see also Bauer et al., supra note 45, at 18; Carah et al., supra note 33, at 825; Harkinson, supra note 13. 
in late August and September, usually due to water reduction or elimination from extensive marijuana farming." 99

This section has explored some of the environmental conundrums that arise for illegal marijuana cultivation, but what happens when the cultivation and sale of marijuana is legalized? The following section examines how the legalization of marijuana might change both land conservation outcomes and the issues associated with conservation easements.

\section{Legal Marijuana CUltivation}

The legalization of marijuana has brought some marijuana production out of the deep hidden areas of large national forests and conservation lands and onto private lands. ${ }^{100}$ Unlike the above part, there is no subsection here on public lands. Federal public lands are not a location of legal marijuana cultivation, nor are they likely to become so. Nor have I found any examples of legal cultivation on state or local lands.

\section{A. Federal Law}

While marijuana remains illegal at the federal level as a Schedule I narcotic, the states have taken less stringent approaches. The 1970 Controlled Substances Act ("CSA") classifies controlled substances based on capacity for abuse, accepted medical uses, and whether abuse of the substance leads to physical or psychological dependence. ${ }^{101}$ The CSA establishes five categories, Schedules I-V, and places each drug into a Schedule based on factors such as whether the drug has an acceptable medical use or whether the drug has a great potential for abuse or dependence. ${ }^{102}$ Marijuana is a Schedule I narcotic meaning that it has no medical value, imposing a complete ban on cultivation,

99 Nathan, supra note 36.

100 Interestingly, even legal marijuana cultivation often remains explicitly hidden on private lands by law. Local zoning and land-use laws some places require marijuana plants to be hidden from view. For some farms, this means greenhouses. Patricia E. Salkin \& Zachary Kansler, Medical Marijuana Meets Zoning: Can You Grow, Sell, and Smoke That Here?, 62 Plan. \& ENVTL. L. 3, 7 (2010) (explaining that local ordinances may require marijuana to not be visible from the street or public areas). In some municipalities, cultivation must occur inside a locked facility. Id. Generally, it is not clear how hidden the grows must be. Could you hide them with hedges or a fence? Is it about street view, google earth images, or access by drones?

101 Controlled Substances Act, 21 U.S.C. § 811(c) (2018).

102 Controlled Substances Act § 812(b) (2018); see also Drug Scheduling, DEA, http://www.dea.gov/druginfo/ds.shtml (last visited Dec. 28, 2017). 
possession, and use of the drug. ${ }^{103}$ Thus, under the CSA, marijuana is on par with heroin, LSD, and ecstasy. ${ }^{104}$ Cocaine and methamphetamine are classified in a less restrictive category as Schedule II drugs. ${ }^{105}$ Generally, state laws regulate controlled substances concurrently with the federal government and many use the same classification system. ${ }^{106}$ Thus, in many states, marijuana is also a Schedule I narcotic under state law. ${ }^{107}$ Schedule I drugs have the most limitations on research and possession, and by virtue of marijuana's Schedule I classification, it is difficult for researchers to obtain marijuana and to conduct research into its effects or its full potential for medical use. ${ }^{108}$ Furthermore, drug offenses involving drugs in more restrictive Schedules are generally subject to the highest fines and most stringent criminal penalties. 109

103 See Controlled Substances Act \& 812. In Spring 2016, it was widely speculated that the DEA was actively considering whether to reschedule marijuana. See, e.g., Huddleston, supra note 3. However, in August 2016 the DEA announced that it would not begin proceedings to reschedule marijuana. Denial of Petition to Initiate Proceedings to Reschedule Marijuana, 81 Fed. Reg. 53,688, 53,688 (Aug. 12, 2016), https://www.gpo.gov/fdsys/pkg/FR-2016-08-12/pdf/2016-17954.pdf. On January 4, 2018, U.S. Attorney General Jeff Sessions rescinded the Cole Memorandum, the Obama-era policy that relaxed federal enforcement actions for marijuana offenses, and called for ramping up federal enforcement of marijuana. JEFFERSON B. SESSIONS, Memorandum for All United States Attorneys Re Marijuana Enforcement (2018), https://www.politico.com/f/?id=00000160-c219-dcd4-a96b-f739flee0000.

104 Controlled Substances Act $\$ 812$.

$105 \mathrm{Id}$.

106 Cf. 21 U.S.C. § 903 (1970) (stating that the CSA, which necessarily includes its classification schedule, has supremacy only over those state laws that "positive[ly] conflict" with the CSA such that "the two cannot consistently stand together"); TODD Garvey, Cong. Research Serv., R42398, Medical Marijuana: The Supremacy Clause, Federalism, and the Interplay BetWeEn State and Federal LaWs 1 (2012) (discussing how this system of concurrent regulation plays out in the context of varying state-level approaches to medical marijuana); GERALD F. UELMEN \& ALEX KREIT, Drug Abuse AND the LaW SOURCEBOOK \& 1.31 (2017-2018 ed. 1974).

107 See GARVEY, supra note 106.

108 See Brian T. Yeh, Cong. Research Serv., RL34635, The Controlled SubStances Act: Regulatory ReQuirements, at i (2012); Andrew Joseph, DEA Decision Keeps Major Restrictions in Place on Marijuana Research, STAT (Aug. 10, 2016), https://www.statnews.com/2016/08/10/marijuana-medical-research-dea.

109 See Brian T. Yeh, Cong. Research Serv., Rl30722, Drug Offenses: Maximum Fines AND TERMS OF IMPRISONMENT FOR Violations OF THE FEDERAL CONTROlled SubSTANCES ACt AND RELATEd LAws 3 (2012). 


\section{B. States}

Medical marijuana is legal in some form in twenty-nine states, the District of Columbia, Guam, and Puerto Rico. ${ }^{110}$ An early and wellknown legalizer of marijuana for medicinal use is California. California's Compassionate Use Act of 1996 creates an exception to a state ban on marijuana cultivation, sale, use, and possession for medical use. ${ }^{111}$ The 2003 Medical Marijuana amendments protect patients with medical identification cards from arrest for possession and use of the drug. ${ }^{12}$ Pursuant to these laws, marijuana use grew and different scales of legal cultivation emerged.113 In 2016, California voters passed a referendum (Proposition 64) that made sale of marijuana for recreational use legal beginning on January 1, 2018.114

Beyond state-level laws and priorities, local governments may also set restrictions on marijuana cultivation and sale. One of the most popular sites of marijuana cultivation is Mendocino County along California's northern Pacific coast. In the late 1990s and early 2000s, people started buying up land all over Mendocino County in anticipation of legalization of some type. ${ }^{115}$ In 2000, Mendocino

110 State Medical Marijuana Laws, NAT’L Conf. St. Legislatures, http://www.ncsl.org/research/health/state-medical-marijuana-laws.aspx (last visited Dec. 28, 2017); see also 29 Legal Medical Marijuana States and DC, ProCon.OrG, http://medicalmarijuana.procon.org/view.resource.php?resourceID=000881 (last updated Nov. 30, 2017, 4:16 PM).

111 Cal. Health \& Safety Code $\S 11362.5$ (1996). Recreational use of marijuana became legal on January 1, 2018. Thomas Fuller, Recreational Pot is Officially Legal in California, N.Y. TIMES (Jan. 1, 2018), https://www.nytimes.com/2018/01/01/us/legalpot-california.html.

112 In 2003, the California legislature passed the Medical Marijuana Program Act to help the intricacies of the Compassionate Use Act of 1996. Cal. Health \& SAFETy CODE \& 11362.7 (1996).

113 Marijuana advocates sought to expand legal marijuana use beyond medical marijuana to recreational marijuana. They were not successful on their first try. In $2010,46.5 \%$ of California voters voted to legalize the drug for recreational use under Proposition 19. Debra Bowen, Statement of Vote: November 2, 2010, General ELECTION 7 (2011), http://elections.cdn.sos.ca.gov/sov/2010-general/complete-sov.pdf. Six years later, legalization for recreational use passed by $57.1 \%$. California Proposition 64 - Legalize Marijuana - Results: Approved, N.Y. TIMES (Aug. 1, 2017), https:// www.nytimes.com/elections/results/california-ballot-measure-64-legalize-marijuana.

The legalization of the use of marijuana does not mean that the cultivation of cannabis is unregulated.

114 Patrick McGreevy, Californians Vote to Legalize Recreational Use of Marijuana in the State, L.A. TIMES (Nov. 8, 2016), http://www.latimes.com/nation/politics/trailguide/la-naelection-day-2016-proposition-64-marijuana-1478281845-htmlstory.html.

115 Peter Fimrite, Allure of Legal Weed is Fueling Land Rush in Emerald Triangle, S.F. CHRON. (May 28, 2016), http://www.sfchronicle.com/science/article/Allure-of-legal- 
County voters approved Measure $G$, which allowed cultivation of up to twenty-five plants per person. ${ }^{116}$ Mendocino County also made it clear that it would not prosecute mom-and-pop growers who exceeded their allowed number of plants. ${ }^{117}$ While not endorsing the illegal activity, the county sheriff just could not keep up with the growers, and the prosecutor's office does not usually prosecute for anything under two hundred plants for staffing reasons. ${ }^{118}$ This led to many Mendocino residents growing and selling marijuana. The activity was no longer hidden; indeed, the smell was palpable in the town of Willits. ${ }^{119}$ But there was a surge in violent crimes and home invasions (targeting either the plants or the large sums of cash people believed growers to have in their homes). ${ }^{120}$ In 2008, voters repealed Measure $G$ and reduced the number of mature plants per patient to six. ${ }^{121}$ Similar local criminal and land-use laws exist throughout the states with legalized marijuana cultivation.

Recreational marijuana is permitted in nine states and the District of Columbia. ${ }^{122}$ In Alaska, voters passed Alaska Ballot Measure 2: An Act to Tax and Regulate the Production, Sale and Use of Marijuana, which established a Marijuana Control Board to implement a commercial marijuana industry in the state. ${ }^{123}$ In Colorado, voters approved a ballot measure that ultimately resulted in an amendment to the state's constitution that declared that marijuana use is legal for adults over

weed-is-fueling-land-rush-in-7948587.php; Nathan, supra note 36, at 2.

116 See Mendocino, Cal., Ordinance $\$ 9.36$ (2000) (repealed by Mendocino, Cal., ORDINANCE \& 9.37 (2008)).

117 See Nathan, supra note 36, at 2. The statewide limit for personal use was six plants, whereas Measure G allowed Mendocino residents to grow up to twenty-five plants without fear of enforcement efforts from County authorities. See Kevin Fagan, Pot Is Burning Issue on Mendocino Ballot, SFGATE (May 31, 2008, 4:00 AM), http://www.sfgate.com/news/article/Pot-is-burning-issue-on-Mendocino-ballot3212357.php

118 K.C. Meadows, Staffing Losses Curb DA Pot Prosecutions, DAILY J. (July 10, 2009, 12:01 AM), http://www.ukiahdailyjournal.com/article/ZZ/20090710/NEWS/907109648.

119 Nathan, supra note 36 , at 2.

120 Id.

121 See Cal. Health \& Safety Code $\$ 11362.77$ (2003); Mendocino, Cal., ORDINANCE § 9.37 (2008).

122 State Marijuana Laws in 2017 Map, Governing: StATES \& LOCALITIES, http://www.governing.com/gov-data/state-marijuana-laws-map-medical-recreational.html (last updated Sept. 14, 2017).

123 See Alaska STAT. \$§ 17.38.010-17.38.900 (2014); see also Dep't Com., Community, \& Econ. Dev., Alcohol \& Marijuana Control Office: Marijuana FAQs, ST. ALASKA, https://www.commerce.alaska.gov/web/amco/MarijuanaFAQs.aspx (last visited Dec. 28, 2017). 
the age of twenty-one and that marijuana should be taxed in a manner similar to alcohol throughout Colorado. ${ }^{124}$ Voters in Washington likewise approved Initiative 502 which allows for a highly regulated system controlled by the Washington State Liquor and Cannabis Board to tax and regulate marijuana use for adults twenty-one and over in a system similar to that which controls alcohol.125 Oregon permits recreational marijuana use for adults over twenty-one and regulates the industry via the Oregon Liquor Control Commission. ${ }^{126}$ Oregon also allows limited amounts of recreational marijuana to be dispensed to adults over twenty-one through medical marijuana dispensaries that are overseen by the Oregon Health Authority. ${ }^{127}$ Nevada legalized recreational marijuana through a ballot initiative (Ballot Question 2) on November 8, 2016 and marijuana purchase, possession, and consumption of marijuana became legal on January 1, 2017.128 Personal cultivation of marijuana is only allowed for home use when there is not a licensed retailer within twenty-five miles. Plants must be grown inside and must not be visible to outsiders. ${ }^{129}$

\section{Agricultural AND CONSERVED LANDS AS MARIJUANA CUlTIVATION SiteS}

Some areas well-suited to the growing of marijuana are those lands that are either already in other types of agricultural use or lands that have been set aside for conservation. Where those lands are encumbered with land protection mechanisms like deed restrictions, conservation easements, or zoning codes, it is not always clear where marijuana cultivation fits. For the most part (and in all circumstances that I am aware of), marijuana production was not contemplated by the drafters of the agreements and laws at issue. And, as Ryan Stoa has

124 Colo. CONST. art. XVIII, § 16.

125 Washington Initiative Measure No. 502, An Act Relating to Marijuana 1 (2011), http://sos.wa.gov/_assets/elections/initiatives/i502.pdf; Recreational Marijuana Fact Sheet, WASH. ST., LIQUOR \& CANNABIS BOARD, http://www.liq.wa.gov/mj2015/factsheet (last visited Dec. 28, 2017).

126 See Or. Rev. Stat. §§ 475B.010-475B.395 (2015); Oregon Measure 91, Control, Regulation, and Taxation of Marijuana and Industrial Hemp Act (2014), http://www.oregon.gov/olcc/marijuana/Documents/Measure91.pdf.

127 See Recreational Marijuana, OREGON.GOV, http://www.oregon.gov/olcc/marijuana/ pages/default.aspx (last visited Dec. 28, 2017).

128 Marijuana in Nevada: Know the Law, NevADA.gov, http://marijuana.nv.gov/ Legal/Legal_Use (last visited Feb. 2, 2018).

129 Marijuana in Nevada: Growing at Home, NeVADA.GOv, http://marijuana.nv.gov/ Legal/GrowingAtHome (last visited Feb. 2, 2018). 
pointed out, states have not addressed agricultural issues in the debates and legislation surrounding marijuana legalization. ${ }^{130}$

Because of the intensity of environmental impacts from illicit cultivation, the shift to growing marijuana openly and under the rubric of best agricultural management practices could yield some quick environmental benefits (but perhaps only when measured against previous illegal use of the land, which is not a great yardstick if the contrast is conservation use). I consider the implications for land conservation along two lines. First, I examine the shift in land use itself. How is marijuana cultivation fitting with existing land uses and community goals? In considering this question, I look to zoning laws, agricultural protection and promotion mechanisms, and land conservation measures. Second, I examine the implications for environmental pollution laws on marijuana grows. One hopes for proper pesticide use and implementation of environmental protection measures. Yet, pesticide regulation has not yet included marijuana in its testing, and it is not clear which pesticides are appropriate for the plant and what types of chemicals may be passed on to consumers. ${ }^{131}$ There may be some solace in the idea that legitimate farmers are not likely to use pesticides whose entire usage is banned in the United States, but we have no clear idea on the effects of pesticides on cannabis plants in part because of the limitations on marijuana research. With legalization of marijuana cultivation, one might expect oversight for water use and pollution. However, in many cases environmental protection laws occur at the federal level and leaves tricky questions regarding environmental permitting.

\section{A. Zoning}

The key way that local governments shape their communities is through zoning. Zoning laws, which exist in most but not all communities, take various forms. ${ }^{132}$ In general though, they detail permitted land uses, explaining where certain activities will be allowed. ${ }^{133}$ Sometimes they contain greater detail setting forth the specific form of the community with rules about building heights and

130 Ryan B. Stoa, Marijuana Agricultural Law: Regulation at the Root of an Industry, 69 FLA. L. REV. 297, 311 (2017).

131 See Stone, supra note 31, at 285.

132 See generally Daniel R. Mandelker \& Michael Allan Wolf, Land Use Law § 4 (6th ed. 2014) (providing an overview of these various forms).

133 See generally id. 
styles or setbacks. ${ }^{134}$ In the context of marijuana cultivation, zoning rules might simply explain where it is allowed or may go further to dictate the details of fences, signs, and other matters.

In all cases, zoning occurs at the local level.135 Even where marijuana cultivation is legalized in a state, local governments are not required to allow marijuana cultivation and use unless the state law specifically preempts the local governments' ability to regulate local land uses and businesses (although none of them do). ${ }^{136}$ As with other landowners, marijuana growers must comply with local land-use laws. The general idea is that local governments get to shape what their community looks like as long as they do not violate the federal or state constitutions or other legal restrictions. ${ }^{137}$

Some local governments have amended their zoning codes to address marijuana cultivation directly. ${ }^{138}$ Where governments have not done so, there can be confusion as to whether (and to what extent) marijuana cultivation is allowed. There are a few general patterns. In many areas, local governments amended or passed zoning laws directly on point after legalization. ${ }^{139}$ A common response is to enact moratoria on marijuana activities (if for no other reason than to create

$134 C f$. id. $\$ 4.16$ (discussing the statutory authority for municipalities' ability to regulate building characteristics based on zoning considerations).

135 For a useful zoning map showing how local governments in Washington State have zoned land for marijuana businesses, see Marijuana Regulation in Washington State, MRSC: LOC. Gov. SuCCESS (Dec. 5, 2017) http://mrsc.org/Home/ExploreTopics/Legal/Regulation/Recreational-Marijuana-A-Guide-for-Local-Governmen.aspx.

136 See, e.g., Bob Ferguson, Whether Statewide Initiative Establishing System for Licensing Marijuana Producers, Processors, and Retailers Preempts Local Ordinances, WASH. ST. OfF. ATT'Y GEN. (Jan. 16, 2014), http://www.atg.wa.gov/ago-opinions/whether-statewideinitiative-establishing-system-licensing-marijuana-producers (presenting a letter from the Washington State Attorney General to the Chair of the Washington State Liquor Board wherein the Attorney General states that the legalization law does not preempt local zoning ordinances); Kate Maxwell, Cannabis Now Considered Agriculture, Willits News (Feb. 10, 2016, 9:32 AM), http://www.willitsnews.com/article/NR/20160210/NEWS/160219981; Salkin \& Kansler, supra note 100, at 7.

137 See generally MENDELKER \& WOLF, supra note 132, § 2.01.

138 See Jeremy Németh \& Eric Ross, Planning for Marijuana: The Cannabis Conundrum, 80 J. Amer. Plan. Assoc. 6, 6-8 (2014) (describing different local government responses to marijuana legalization); Salkin \& Kansler, supra note 100, at 7.

139 Some jurisdictions issued moratoria after legalization, putting a hold on the siting of new marijuana activity pending a chance for consideration by the local governments. This is a common tool employed by local governments when new uncontemplated land uses arise. The moratorium tool gives the local government a chance to consider the new land use and how it intersects with current land uses and community values. Salkin \& Kansler, supra note 100, at 3. After legalization, many municipalities in Washington State banned or restricted marijuana growth and sale. 
time to establish a more thoughtful regulatory regime). ${ }^{140}$ In some areas, we have zoning laws that require compliance with all federal laws, including presumably the Controlled Substances Act. In other areas, laws are silent on the issue. Thus, some local governments decide to ban it, some limit it and pass specific zoning and land-use ordinances on point, and others are silent, leaving interested parties and the local judiciary room to interpret whether marijuana growing follows the same zoning and land-use rules as other types of agricultural production.

Where communities have strong objections to marijuana cultivation for a variety of reasons, including environmental concerns, reputation, or social concerns, they can use zoning law to prevent the establishment of marijuana grows within their jurisdiction. As Dilley et al. point out, the voters in favor of marijuana legalization may not be evenly distributed. ${ }^{141}$ In Washington, nineteen of the thirty-nine counties voted against legalization with some communities voting strongly against it. ${ }^{142}$ The zoning power enables those communities to regulate marijuana more strictly based on community goals. ${ }^{143}$ For example, Arapahoe County, Colorado, banned the growing of medical marijuana except for some narrow exceptions for indoor growing. ${ }^{144}$ Conversely, if a community seeks to attract marijuana cultivators and build a local industry based on the substance, it can design generous zoning laws that encourage and facilitate cultivation. The legalization of marijuana therefore need not alter a local landscape where there is political will to oppose it. Yet, passing new laws on any topic can be a slow and contentious process leaving many to complain about either over- or under-development of marijuana cultivation within a community.

Where zoning laws do not address marijuana cultivation, marijuana growing (beyond the small cooperatives, which are residential) should

140 Salkin \& Kansler, supra note 100 , at 3.

141 Julia A. Dilley et al., Community-Level Policy Responses to State Marijuana Legalization in Washington State, 42 INT'L J. DRUG POL'Y 102, 103 (2017).

142 Id.

143 Id. at 106. In their study of marijuana regulation by local governments in Washington State, Dilley et al. found that most local governments have passed legislation governing retail sales of recreational marijuana, with only four percent of the population not taking policy action. Unfortunately for our purposes, they did not study laws regarding marijuana cultivation. But, the pervasiveness of the legislation generally shows that there are likely many local laws governing marijuana cultivation as well. See id.

144 See Arapahoe County, Colo., $\S \S 12-1802$ to 1803 (revised 2015) https://www.arapahoegov.com/DocumentCenter/View/1146. 
logically fall under agricultural use. For example, Oregon's statutes declare that marijuana is a "crop for the purposes of 'farm use' . . and 'farming practice' ... and [that it is generally] [t] he product of an agricultural activity ...."145 The default assumption where zoning law does not directly address marijuana cultivation is to require the same rules as agriculture generally. Some states take a different approach. For example, New York's medical marijuana law characterizes growing as manufacturing, likely in part because growing must occur indoors - making marijuana cultivation look more like a factory than a farm.

Treating marijuana as any other agricultural crop does not jive well with everyone though. Even legalization laws seem to acknowledge that there is something different about this crop. For example, Colorado requires that a marijuana growing operation include an investment in a $\$ 35,000$ operating system and 24-hour surveillance, clearly indicating that there is something special about marijuana plants. ${ }^{146}$ There are no similar requirements for crops that produce alcohol or tobacco. Washington goes even farther in distancing marijuana from other types of farming. According to Washington's statute legalizing marijuana, the terms "agriculture" or "farming" or other similar statutory phrases cannot be construed to include or relate to marijuana unless the term is explicitly defined so that it includes marijuana. ${ }^{147}$ This interpretative approach prevents marijuana cultivation from sliding into agriculture protection and promotion policies without a clear statement from the legislature that marijuana should be included. Such a measure could reduce the possibility of unforeseen consequences by preventing blanket application of agricultural rules and programs to marijuana cultivation, but at the same time, it seems strange to think of cultivation of cannabis plants as something other than agriculture.

A lack of direct attention to marijuana cultivation in the zoning code usually indicates that the community has not considered the issue. Indeed, I could find no example where a community went through a zoning process post-marijuana legalization without including provisions explicitly addressing the issue. Some communities may have examined their state law in the wake of

145 Or. Rev. Stat. § 475B.370(1) (2015).

146 Amy Hamilton, Palisade Residents Protest Approval for Outdoor Marijuana Grow, DAily SENTINEL (Mar. 2, 2015), https://web.archive.org/web/20150305094154/ http://www.gjsentinel.com/news/articles/palisade-residents-protest-approval-foroutdoor-ma.

147 WASH. ReV. CODE § 82.04.213 (2015). 
legalization and simply determined that there was no need to amend the laws. ${ }^{148}$

Communities that amend their zoning codes to address marijuana cultivation often use conditional use permit procedures. For example, in 2015, the Board of Trustees in the town of Palisade, Colorado, approved two zoning ordinances that would enable the conversion of a peach orchard to marijuana plantation. ${ }^{149}$ The town required a conditional use permit for the marijuana cultivation even though farmers do not usually need to apply for special permits to conduct agricultural activities on land zoned for agriculture. 150

Bans sometimes occur not with a specific reference to marijuana but with a local law that prohibits activities or businesses that do not comply with federal laws. This means even a zoning law banning marijuana cultivation may have occurred without contemplation of marijuana cultivation, leading to a stricter limit on the crop than the community might actually desire. A zoning map of Washington shows fourteen municipalities and six counties where no zoning change was needed for marijuana cultivation (presumably it qualified as agriculture under existing zoning). ${ }^{151}$ Local governments in Washington can file objections regarding marijuana growing at a particular location, but the Liquor Control Board does not need to listen to them. ${ }^{152}$

148 See Marijuana Regulation in Washington State, supra note 135 (illustrating that as of August 2017, thirty-nine municipalities and three counties in Washington have not changed their zoning laws since legalization).

149 Bill Hoffmann, Planning Commission Favors Annexation to Grow Peaches and Possibly Marijuana, PEACH TOWN NEWS, June 12, 2014, http://peachtownnews.com/palisadeplanning-commission-favors-annexation-request-to-grow-peaches-and-possibly-

marijuana/; Nancy A. McLaughlin, Growing Marijuana as "Agriculture" on ConservationEasement Protected Land, NonProfit L. PROF BLog (Mar. 2, 2015), http://lawprofessors.typepad.com/nonprofit/2015/03/growing-marijuana-as-agriculture-onconservation-easement-protected-land.html.

150 See Marjorie Haun, Colorado Town Trustees Do "End Run" Around Citizens to Allow Marijuana Operation in City Limits, WATCHDOG.ORG (Mar. 4, 2015), http://watchdog.org/203829/marijuana-palisade-trustees (providing that the Colorado statute requires any marijuana farm to be at least 1,000 feet from public buildings such as schools and churches); see, e.g., MEghan Thoreau, BroOkings County CONDITIONAL Use PERMit REQUEST (Sept. 9, 2014), http://brookingscountysd.gov/ AgendaCenter/ViewFile/Item/1067? fileID=1565 (demonstrating that there can be exceptions for what might be categorized intense agricultural practices like concentrated animal feeding operations).

151 Marijuana Regulation in Washington State, supra note 135. This map does not single out land-use regulations pertaining to cultivation.

152 Id. 
Seattle serves as an example for strategies local governments undertake within a state that legalized marijuana cultivation. The City of Seattle has marijuana zoning restrictions that limit the amount of growing, processing, selling, and delivery of marijuana and related products in city limits. ${ }^{153}$ The Seattle Land Use Code creates thresholds of marijuana growing and has rules about where major marijuana activity can occur. ${ }^{154}$ Growing marijuana qualifies as a "major marijuana activity." 155 Major marijuana activities require a permit from the state Liquor Control Board. ${ }^{156}$ While legalization is a state process, local governments have the ability to determine when permits are required and to limit areas where major marijuana activities are allowed.

Oregon classifies growing marijuana as a "farm use."157 This means marijuana can be grown in exclusive farm use zones. Commercial activity is prohibited. Therefore, you cannot sell or conduct other commercial activities in the same place that you grow recreational marijuana in Oregon. You can have small-scale processing facilities but not large-scale ones. Counties have the ability to extend the permissible cultivation areas to other farm or forest use zones. The state suggests that communities who do not want to have any growing of marijuana in their jurisdiction simply amend their zoning codes to remove the exclusive farm use category. In Oregon, local governments either opt out of participating in the growing of marijuana (thus banning the practice), or they pass local zoning laws to set the rules regarding the practice.

The characterization of marijuana cultivation as agriculture may also limit the ability of small producers to cultivate the plant in their

153 Seattle, Wash., Mun. Code $\$ 23.42 .058$ (amended Jan. 12, 2016).

154 See Seattle Dept. of Constr. \& Inspections, Marijuana Zoning Restrictions, SEATTLE.GOV, http://www.seattle.gov/dpd/vault/marijuanazoning/accomplishments/ default.htm (last visited Feb. 15, 2018).

155 Seattle, Wash., Mun. Code § 23.42.058; Seattle Dept. of Constr. \& Inspections, Marijuana Code, SEATTLE.GOV, http://www.seattle.gov/dpd/codesrules/ codes/marijuanacode/default.htm (last visited Feb. 15, 2018).

156 See Producer License Descriptions and Fees, WaSH. St. LiquOR \& CANNABIS BOARD, http://lcb.wa.gov/mjlicense/producer_license_discriptions_fees (last visited Feb. 15, 2018) (detailing different types of licenses for different marijuana activities). The state only had a thirty-day window for applying for producer licenses in 2013. As of February 2, 2018, the Washington State Liquor and Cannabis Board had not reopened the window and accepted any new applications. Holders of licenses do have the power to transfer them though, indicating that new producers can enter the market when others exit.

157 Guide to Recreational Marijuana in Exclusive Farm Use Zones - 2015, (Sept. 14, 2015), http://www.oregon.gov/LCD/docs/Guide_to_Rec_Marijuana_and_Land_Use.pdf. 
homes or retard the development of indoor growing sites. For example, Aspen, Colorado, does not permit marijuana cultivation (even indoor operations) in service, commercial, or industrial zone districts - only in agricultural use districts. 158

While there are disputes among and within communities regarding where marijuana cultivation should be permitted, current land-use patterns suggest that we will see conversion of existing agricultural land as opposed to bringing new lands under cultivation. This conversion may not have a large environmental impact, but it does change a community. Where federal, state, and local laws encourage and facilitate protection of agricultural lands and communities, does the conversion of that land to marijuana cultivation matter? This may be a particular issue in nuisance suits. Patricia Salkin suggests that municipal attorneys may use nuisance suits to prevent certain marijuana sales, ${ }^{159}$ but it is unclear how this doctrine might be invoked for plant cultivation. In San Jose, California, a deputy city attorney argued that because growth and distribution of the drug is illegal under federal law, dispensing facilities are a per se nuisance. ${ }^{160}$ The argument was not tested in court because San Jose had a moratorium in place until 2014.161 It has since issued regulations governing medical marijuana use, but has banned recreational marijuana use and distribution. ${ }^{162}$ Nuisance suits might be even more challenging for the cultivation of marijuana (versus marijuana dispensaries) because of Right to Farm laws that protect agricultural operations from nuisance suits, but the contents of such state statutes vary greatly. 163

\footnotetext{
158 Salkin \& Kansler, supra note 100 , at 7.

159 Id. at 3.

160 Memorandum from Richard Doyle, San Jose City Attorney, to Rules and Open Govt. Comm. (Jan. 21, 2010), http://www.sanjoseca.gov/DocumentCenter/View/ 42259.

161 See San Jose, Cal., Ordinance 29240 (June 17, 2014), http://www.sanjoseca. gov/DocumentCenter/View/32898.

162 Ramona Giwargis, San Jose City Council Approves Ban on Recreational Marijuana Sales, Mercury News (Nov. 3, 2016, 6:24 AM), http://www.mercurynews.com/ 2016/11/01/san-jose-city-council-approves-ban-on-recreational-marijuana-sales. But see Medical and Non-Medical Cannabis in San Jose, SanJoseCA.Gov, http://www. sanjoseca.gov/medicalmarijuana (last visited Feb. 18, 2018).

163 See Terence J. Centner, Agricultural Nuisances: Qualifying Legislative "Right-ToFarm" Protection Through Qualifying Management Practices, 19 LAND UsE POL'Y 259, 261 (2002) (describing Right to Farm laws and the variations among states); Laws, FARMLAND INFO. CTR., http://www.farmlandinfo.org/law?field_law_category_tid=289\& field_topic_tid=226\&field_state_tid=All (last visited Feb. 18, 2018) (providing access to various state Right to Farm statutes) [hereinafter FIC]. Most protections under
} 


\section{B. Farm Subsidies, Programs, and Tax Breaks}

Many federal, state, and local programs protect and promote agricultural lands. It is not clear which of those programs are still available when farmers choose to grow marijuana as their crop. The conservation benefits of agricultural land are numerous and variable. ${ }^{164}$ Agricultural land can provide habitat (particularly for birds), open space, scenic views, and water recharge areas. ${ }^{165}$ Depending on the landscape and potential other land uses, the benefits can be far reaching. This is recognized in state and federal laws.

Through the Farm Bill, the United States Department of Agriculture offers many financial and technical support programs for farmers. These include things like financial assistance for veterans, programs to protect air and water, and other environmental protection initiatives. ${ }^{166}$ While there is no specific policy statement on point, growers of marijuana are not able to take advantage of these programs. Nor can they avail themselves of federal crop insurance or disaster relief programs. ${ }^{167}$ The federal government will not allow federal irrigation water to be used to grow marijuana anywhere, even in states where cultivation is legal. ${ }^{168}$

right to farm laws only pertain to land already under production, not new agricultural lands. Some laws also have exceptions for changes in crops or techniques that might fail to protect marijuana operations. See generally David N. Bengston et al., Public Policies for Managing Urban Growth and Protecting Open Space: Policy Instruments and Lessons Learned in the United States, 69 LANDSCAPE \& URB. PLAN. 271, 277-78 (2004) (describing regulatory approaches to protect agricultural land).

164 See, e.g., Aaron Schwartz \& Maya Kocian, Beyond Food: The Environmental Benefits of Agriculture in Lancaster County, Pennsylvania 2, 5 (2015); François Bonnieux et al., Estimating the Supply of Environmental Benefits by Agriculture: A French Case Study, 11 Envtl. \& Res. ECON. 135, 135 (1998); G. Philip Robertson et al., Farming for Ecosystem Services: An Ecological Approach to Production Agriculture, 64 BIOSCIENCE 404, 404 (2014).

165 See, e.g., Paul R. Elsen et al., The Importance of Agricultural Lands for Himalayan Birds in Winter, 31 CONSERVATION Biology 416, 416 (2016).

1662014 - Farm Bill — Veteran Farmers ^ NRCS, U.S. DEP'T AGRICULtURE, https://www.nrcs.usda.gov/wps/portal/nrcs/detail/national/programs/farmbill/?cid= stelprdb1256753 (last visited Feb. 18, 2018).

167 Stoa, supra note 130, at 303-04.

168 Associated Press, Feds Don't Want Irrigation Water Used to Grow Pot, Denver Post (Apr. 27, 2016, 7:34 AM), http://www.denverpost.com/2014/05/20/feds-dontwant-irrigation-water-used-to-grow-pot; see also Use of Reclamation Water or Facilities for Activities Prohibited by the Controlled Substances Act of 1970, U.S. BUREAU ReClamation (May, 15 2017), https://www.usbr.gov/recman/temporary_releases/ pectrmr-63.pdf. 
States also often have tax benefit programs offering reductions in both income taxes and property tax. ${ }^{169}$ For example, California's Williamson Act offers property tax savings to farmers who agree to keep land in agricultural production for at least ten years. ${ }^{170}$ While the program is limited to lands with certain soil types and water availability ${ }^{171}$ and is being slowly phased out, ${ }^{172}$ there appears no reason why marijuana cultivation would not qualify. Because many agricultural programs did not contemplate marijuana use when created, conversion to the crop raises important concerns. When California voters legalized marijuana, did they also intend to create tax benefits for growers? Similar tax programs exist in many states. ${ }^{173}$

\section{Conservation Easements}

Farmers also periodically receive state and federal tax benefits by donating development rights to a government entity or nonprofit organization in the form of a conservation easement. For agricultural conservation easements to be eligible for federal tax benefits, they must meet the requirements of section 170(h) of the Internal Revenue Code, which means that the farmland protection must provide either scenic enjoyment or be "pursuant to a clearly delineated Federal, State, or local governmental conservation policy, and will yield a significant public benefit."174 Assuming that marijuana grows can meet this requirement (which is admittedly questionable where farmers are required to restrict views to the plants limiting scenic claims, but possible if the farm is in a designated agricultural protection district), theoretically they should not be able to take a federal tax deduction for engaging in activity that is contrary to federal law. Denial of deductibility, however, would not dissolve the conservation easement,

169 See Salkin \& Kansler, supra note 100, at 7 (concluding that it "remains to be seen whether medical marijuana will be treated as an agricultural crop for purposes of special protections and for tax exemptions" and noting the uncertainty of its inclusion in special agricultural districts).

170 CAL. Gov't CODE § 51243 (2018); Jessica Owley \& Amy Morris, The New Agriculture: From Food Farms to Solar Farms (Aug. 21, 2017) (unpublished manuscript) (on file with author) (describing the workings of the Williamson Act and policies promoting agriculture in California).

171 See Cal. Dept. of Conservation, The California Land Conservation Act 2014 Status Report: THE Williamson ACt 7, 9 (2014).

172 Owley \& Morris, supra note 170.

173 See FIC, supra note 163 (assembling state laws related to promotion or protection of agriculture).

174 I.R.C. \& 170(h)(4)(A)(iii)(II) (2018). 
which is governed by state property law. What is even less clear is what happens when a farmer has already received the tax deduction for placement of the conservation easement and then years later switches crops. Does the federal government have any say in what happens on this land that benefited from a federal program? What about taxpayers who shared the burden of financing the land conservation effort?

The controversial property in Palisade, Colorado, discussed above had an additional impediment beyond community resistance. The land was protected by a conservation easement held by the Mesa Land Trust. ${ }^{175}$ When the conservation easement was originally entered into, marijuana growing was not an otherwise legal use of the land. The conservation easement, therefore, did not speak to the issue, with the framers likely assuming that growing of illegal drugs was handled by other areas of the law and did not need to be a provision of the agreement. The conservation easement encumbering this land restricts the land to agricultural use. ${ }^{176}$ It does so because the Mesa Land Trust believes that preventing conversion of agricultural land to other uses yields conservation and cultural benefits. ${ }^{177}$

The Mesa Land Trust, now named the Colorado West Land Trust, has generally taken the position that it cannot tell farmers what to grow on land protected by agricultural conservation easements. ${ }^{178}$ If a conservation easement does not affirmatively prohibit something, it should be allowed. This is the conclusion reached by this land trust, but it does not seem a necessary conclusion. Should conservation easements have a presumption that activities at odds with federal law are impermissible? Must the conservation easements make that statement explicitly? If we allow conservation easement properties to become locations of marijuana cultivation, it may raise issues of deductibility. ${ }^{179}$ Should the landowner be eligible for a charitable tax donation for creation of the conservation easement? It may not be as much of a concern with agricultural conservation easements that are more likely to have been purchased, but we could see similar questions arising for donated conservation easements that are protecting the land from a variety of negative land uses. Does

175 Hamilton, supra note 146.

176 See Kelsey Perkins, Controversy over Palisade Pot Growing Site Continues, NBC 11 News (Mar. 2, 2015, 7:00 AM), http://www.nbcllnews.com/home/headlines/ Palisade-pot-growing-site-controversy-continues-294589211.html.

177 Colo. W. Land TR., https://cowestlandtrust.org (last visited Feb. 18, 2018).

178 Perkins, supra note 176.

179 See generally I.R.C. \& 170 (2018). 
marijuana cultivation (or other acts impermissible under federal law) have any tax implications when it occurs long after the deduction has been made? Perhaps even after the original landowner has passed away? There could also be legal implications for land trusts themselves. Might they jeopardize their 501(c)(3) tax status by facilitating something illegal under federal law? They might be fine with their state charters if it is the state who has legalized marijuana cultivation, but that may not be enough.

A case took a different direction in the State of Washington. There, a property was encumbered by a conservation easement held by a local land trust, the Whidbey Camano Land Trust, ${ }^{180}$ and was purchased for $\$ 75,000$ in part by federal funds. ${ }^{181}$ Owners of land encumbered by the conservation easement applied for a license to run a recreational marijuana-based business. ${ }^{182}$ The land trust opposed the license because it did not want the landowners to do something that violated federal law. ${ }^{183}$ At least facially, the land trust's decision did not have to do with the conservation goals or characteristics of the land.

Is marijuana just a choice of crop, or is it something else? Does the requirement of a special permit indicate that this is a special case and should be treated differently? Marijuana cultivation is another example of an uncontemplated land use for conservation easements. In some ways, marijuana plantations are no different from cell phone towers, wind turbines, or fracking. ${ }^{184}$ It is a new (and controversial) use of land that was not contemplated by drafters of land-use restrictions, and now we have to determine whether the restrictions will stretch to cover these uses. This is an important issue with perpetual land restrictions where there will inevitably emerge land uses that no one had contemplated. Generally, the approach is to allow the new use where it does not disrupt the conservation purposes

180 Whidbey CAMANo LAND TR., www.wclt.org (last visited Feb. 18, 2018).

181 Coupeville Marijuana Business Pulls Permit Application, WhidBey News-Times (Aug. 25, 2014, 12:37 PM), http://www.whidbeynewstimes.com/news/coupevillemarijuana-business-pulls-permit-application.

182 See id.

183 Id. (quoting Whidbey Land Trust Executive Director as saying, "The Land Trust has no position on this issue... . We just have to make sure property owners comply with easement regulations").

184 See Jessica Owley \& Collin Doane, Exploiting Conservation Lands: Can Hydrofracking Be Consistent with Conservation Easements?, 66 U. KAN. L. REV. 93, 14546 (2017). See generally Gerald Korngold, Conservation Easements and the Development of New Energies: Fracking, Wind Turbines, and Solar Collection, 3 LA. ST. U. J. ENERGY L. \& RES. 101, 102-03 (2014). 
of the conservation easement. 185 This can be tricky where the conservation easement has multiple purposes that now appear to conflict with each other. ${ }^{186}$ Or where we simply lack the information to determine whether the use seems to coincide with the purposes.

Land trust concerns about marijuana cultivation also put the land trust in a new position of actually needing to inspect what crops are grown. When land trusts monitor the land for conservation easement compliance, this is not generally one of the things they examine. The scrutiny is usually on the boundaries of buildings and cultivation. They look for construction, dumping, and structural issues that do not require biological or agricultural expertise. ${ }^{187}$ Farmers do not regularly update the conservation easement holders about their changes in crops. It is interesting to think what this law might mean for the obligations of land trust and the annual monitoring requirements. Will the IRS get upset with a land trust that fails to identify and protest a crop change?

When the California Department of Conservation issued a statement saying that cannabis is considered by the state as agriculture and qualifies for a permitted activity on agricultural conservation easements, ${ }^{188}$ the land trust community was uncertain how to proceed. ${ }^{189}$ Many conservation easements contain clauses requiring compliance with all federal, state, and local laws. ${ }^{190}$ Where a

185 See Owley \& Doane, supra note 184, at 123.

186 See Jessica Owley \& Adena Rissman, Trends in Private Land Conservation: Increasing Complexity, Shifting Conservation Purposes and Allowable Private Land Uses, 51 LAND USE POL'Y 76, 77 (2016) (examining changes in conservation easements overtime and finding, inter alia, an increasing number of purposes identified in the average conservation easement).

187 In this case, I speak from experience. As a land trust volunteer, I have helped monitor agricultural conservation easements for compliance. I did not examine the crops while doing so. And while I have faith I could identify a mature marijuana plant, I am less certain about seedlings or ground preparation techniques. With compliance monitoring only happening once a year (and usually occurring with notice to the landowners), I could easily miss marijuana cultivation.

188 Statement from the Cal. Dep't of Conservation, Div. of Land Res. Prot., Cultivation of Medical Marijuana and the Williamson Act (July 2016), https://web.archive.org/web/20170421025416/http://www.conservation.ca.gov/dlrp/ lca/Documents/WA\%20Medical\%20Marijuana_7.15.2016.pdf.

189 There is a very active land trust community listserv with hundreds of subscribers. Upon release of the statement, there were several emails discussing its implications and concerns about marijuana cultivation in general. The participants in the conversation all agreed it was best to prohibit cultivation on any lands encumbered with conservation easements.

190 See, e.g., Jane Ellen Hamilton, Conservation Easement Drafting and DOCUMENTATION 196 (Sylvia Bates ed., 2008), https://oregonlandtrusts.org/wp- 
conservation easement requires organic agriculture, there might be a problem because organic certification is a federal program and marijuana growers cannot participate. ${ }^{191}$

Some conservation easement attorneys and land trust staff worried that (1) such language would suggest that it was not an acceptable land use and would be a violation of the conservation easement and (2) asset forfeiture laws might come into play. ${ }^{192}$ Asset forfeiture allows the federal government to seize property involved in illegal activity. ${ }^{193}$ It usually involves seizure of proceeds or instruments of crime, including property where drugs are stored, produced, or sold. While not limited to drug-related crimes, a large percentage of asset forfeiture cases in the United States are linked to drug activity. Asset forfeiture comes in two flavors: criminal and civil. Criminal forfeiture allows seizure of proceedings of criminal activity as well as goods and property involved in carrying out the enterprise. ${ }^{194}$ Civil forfeiture law allows seizure of goods and property with proven ties to crime, but there is no requirement that the property owner herself be convicted of crime. ${ }^{195}$ Furthermore, the person whose goods have been seized generally has the burden of proof demonstrating that the property should not be seized. ${ }^{196}$ A property owner or a conservation easement

content/uploads/2017/05/DL_CE_Drafting_05062010-1.pdf (including the following term in its guidance for crafting conservation easements: "Local, State and Federal Law in Effect. The Property remains subject to all applicable local, state and federal laws and regulations"); Sample Conservation Easement Language, VIRGINIA.GOv, http:// www.dcr.virginia.gov/land-conservation/document/lcsampease.pdf (last visited Feb. 18, 2018) ("All structures and uses shall conform with all applicable local, state and federal ordinances, statutes and regulations."). But see Model Grant of Conservation Easement and Declaration of Covenants, PA. LAND TR. Ass'N, http://conservationtools.org/guides/13model-conservation-easement (last visited Feb. 18, 2018) (demonstrating that many conservation easements do not contain this phrase, and that there is no legal requirement that they do so).

191 See Stoa, supra note 130, at 343.

192 Confidential conversation from a land trust listserv in the Spring of 2017, supra note 189.

193 See Adrian Fernandez Baumann, A Carrot and Stick for Pot Farmers, E. BAY EXPRESS (Aug. 12, 2015), https://www.eastbayexpress.com/oakland/a-carrot-and-stickfor-pot-farmers/Content?oid=4454890.

194 See Michael Goldsmith \& Mark Jay Linderman, Asset Forfeiture and Third Party Rights: The Need for Further Law Reform, 1989 DukE L.J. 1254, 1256.

195 See Sarah Stillman, Taken, NEw YORKER (Aug. 2013), https://www.newyorker.com/ magazine/2013/08/12/taken (reporting a yearlong investigation into the workings of civil forfeiture and the injustices associated with its abuse).

196 See id. 
holder could lose property through either civil or criminal forfeiture programs. ${ }^{197}$

Attorney General Jeff Sessions announced his goal of increasing asset forfeitures in July 2017 along with a tougher stance on marijuana and officially rescinded the previous administration's more lenient enforcement policies in January 2018. ${ }^{198}$ Such developments make landowners and conservation easement holders concerned for the implications of allowing marijuana cultivation to proceed. A landowner could lose her property for cultivating marijuana, and it is unclear what the implications would be for land trusts holding rights in that property. There is no case law indicating whether asset forfeiture would invalidate a conservation easement. Hopefully, the new landowner (the government or whoever purchases the land at the government sale) would still have the obligation to comply with the restriction. Even if so, the land trust would have to work with the landowners who may not have acquired the property with land conservation in mind to ensure conservation easement compliance. Some land trusts worry about asset forfeiture even if the cannabis is grown on a non-protected area of the same parcel, as the entire land might be at risk. ${ }^{199}$ Where land trust property might be at varying risk depending on administrative changes, land trusts holding perpetual property rights have an obligation to be wary. Indeed, a decision to allow marijuana cultivation could endanger tax-exempt nonprofit organization status or invoke scrutiny from the state attorneys general worried that a land trust is not complying with its charter, not to mention the potential push back from members, donors, and neighbors.

197 See Sarah Stillman, Jeff Sessions and the Resurgence of Civil-Asset Forfeiture, NEW YORKER (Aug. 15, 2017), http://www.newyorker.com/news/news-desk/jeff-sessionsand-the-resurgence-of-civil-asset-forfeiture (describing legal changes in New Mexico, Connecticut, Nebraska, New Hampshire, and elsewhere as some states have abolished or limited the extent of forfeiture seizures but largely not the states with large marijuana growing operations). However, as marijuana cultivation is legal at the state level, it is federal forfeiture processes that puts landowners at risk with marijuana operations. U.S. Attorney General Sessions has also indicated that he supports a program of federal adoption where state authorities can invoke the federal laws to seize property with the benefit that the federal government allows the state to retain up to eighty percent of seized assets.

198 Id. (describing how Attorney General Sessions has called for an inquiry into the link between marijuana and violent crime and has compared marijuana to heroin).

199 Confidential conversation from a land trust listserv in the Spring of 2017, supra note 189 . 


\section{Environmental Protection Laws}

If our hopes for improved environmental benefits from legalization rely upon the ability to bring these grows under public oversight, the benefit may be limited. Farmers often must comply with several federal laws in their operations. For example, certain grading and earth shaping exercises that prepare ground for cultivation are governed by the Clean Water Act, and one must obtain a section 404 permit to proceed. ${ }^{200}$ Where endangered species are present, one may need a permit (or at least a review process) under the federal Endangered Species Act. ${ }^{201}$ There may also be implications under the Clean Air Act and Safe Drinking Water Act. ${ }^{202}$ Permit issuance under any of these programs has the ability to trigger environmental review under the National Environmental Policy Act.203 Yet, for marijuana farms, this creates a conundrum. How can they comply with federal environmental laws while running afoul of federal criminal laws and tax policy? Obtaining federal permits is not possible, while penalties for lack of compliance remain.

In many cases, the federal agencies have delegated the environmental protection programs to state agencies. Under this cooperative federalism model, perhaps growers can obtain state permits. It does not make them legal enterprises in the eyes of the federal government, but it does minimize their violations and perhaps deters federal scrutiny. Attorneys at Harris and Bricken (a cannabis industry law firm) noted that in 2015 they were just beginning to see states enacting laws about water and air quality surrounding

200 See U.S. Envtl. Prot. Agency, Memorandum: Clean Water Act Section 404 Regulatory Program and Agricultural Activities (May 3, 1990), https://www.epa.gov/cwa404/memorandum-clean-water-act-section-404-regulatory-program-and-agriculturalactivities; Clean Water Act Section 404 and Agriculture, U.S. EPA, https://www.epa.gov/cwa404/clean-water-act-section-404-and-agriculture (last visited Feb. 18, 2017).

201 See Amara Brook et al., Landowners' Responses to an Endangered Species Act Listing and Implications for Encouraging Conservation, 17 CONSERVATION BIOLOGY 1638, 1644 (2003); Merenlender et al., supra note 73, at 66 (explaining that the Endangered Species Act implements a regulatory approach to protect threatened habitats or to preserve agricultural land).

202 See, e.g., Agriculture: Laws and Regulations that Apply to Your Agricultural Operation by Farm Activity, U.S. EPA, https://www.epa.gov/agriculture/agriculturelaws-and-regulations-apply-your-agricultural-operation-farm-activity (last visited Feb. 18, 2018).

203 See National Environmental Policy Act, 42 U.S.C. $\S \S 4321-4347$ (2018). See generally Bradley C. Karkkainen, Whither NEPA?, 12 N.Y.U. ENVTL. L.J. 333, 352-55 (2004) (discussing environmental review). 
marijuana cultivation, sale, and use. ${ }^{204}$ In Washington State, the Puget Sound Clear Air Agency told producers that they must comply with air quality regulations, including applying for permits that include things like controlling odor and providing information about any hazardous materials or solvents used.205 The producers must also submit plans of the agricultural fields and facilities and demonstrate how they are monitoring and controlling air pollution. ${ }^{206}$ Such scrutiny and control does not happen with illegal grows and black market marijuana, indicating that legalization can yield some environmental benefits.

Environmental enforcers have trouble determining when grows are legal or illegal. ${ }^{207}$ In California, the Regional Water Quality Control Board regulates discharges that could affect the quality of the waters of the state. ${ }^{208}$ This puts the Board in the position of regulating discharges into the waters of the state, including discharges from legal or illegal marijuana cultivation. Staff have found "extensive evidence demonstrating that these discharges can and do affect the quality of waters of the state." 209 The State has taken the position that the legality of the activity under federal or state law is of little importance to it and that it will simply enforce the water quality laws without concerning itself about drug laws. 210

Legal ambiguities related to the cultivation and possession of marijuana have little bearing on the Water Boards' regulatory authority; the Boards have the authority to enforce water

204 See Hilary Bricken, Marijuana's Environmental Impact and the Laws that Regulate It, CANNA L. Blog (Mar. 26, 2015), http://www.cannalawblog.com/marijuanasenvironmental-impact-and-the-laws-that-regulate.

205 Id.; Permitting \& Registration, Puget SOUnd Clean Air AgenCy, https://www.pscleanair.org/213/Permitting-Registration (last visited Feb. 18, 2018).

206 Bricken, supra note 204; Permitting \& Registration, supra note 205.

207 See Christian Carrigan et al., Strategy Regulation and Enforcement of Unauthorized Diversions; Discharges of Waste to Surface and Groundwater CAUSED BY MARIJUANA CULTIVATION 1 (2014), http://www.waterboards.ca.gov/ centralvalley/water_issues/cannabis/education_outreach/ccwdrp_2014strategy.pdf.

$208 \mathrm{Id}$. at 3-4 (noting that the Board has a non-delegable duty to prescribe requirements that will ensure that the discharge will comply with the applicable water quality control plan).

209 Id. at 4.

210 Id.; Memorandum from Samantha Olson to North Coast Regional Water Quality Control Board, Regulation of Waste Discharges from Marijuana Cultivation (Aug. 19, 2013), reprinted in CARRIGAN ET AL., supra note 207; see, e.g., Consideration of an Administrative Civil Liability Order, CENT. VAlley WATER BOARD, http://www.waterboards.ca.gov/centralvalley/board_decisions/tentative_orders/1506/ 21_baker/2_baker_buff.pdf (last visited Feb. 18, 2018) (describing an enforcement action against an apparently legal marijuana cultivation operation). 
quality laws despite the discontinuity between California law... and the federal Controlled Substances Act..., in order to avoid any conflict with federal law, when the Water Boards exercises their regulatory authority over marijuana cultivators, it will explicitly state that it does not in any way authorize, endorse, sanction, permit, or approve the cultivation, use, or sale of marijuana or any other illegal activity. ${ }^{211}$

In California, there is one notable example of a pot farmer who was fined for violating the Clean Water Act and some state water regulations.212 Other California agencies have taken similar approaches. The California Department of Fish and Wildlife enforces the state Fish and Game code on properties where marijuana is being cultivated without seemingly taking a stance regarding the legality of cultivation. It does, however, impose higher civil penalties in areas of marijuana cultivation. ${ }^{213}$

\section{DISCUSSION AND CONCLUSION}

Assessing the environmental impacts of marijuana legalization is a question without one clear answer. It can be hard to gauge the impacts of legal marijuana cultivation because we need to know what we are comparing it to. Are we assessing the environmental impacts of illegal cultivation against the impacts of legal cultivation? Are we comparing the environmental impacts of growing marijuana to the impacts of growing other crops? The key question is to ask but for the legalization of marijuana what situation would we have? That means we have to understand the implications of legal versus illegal growth. Does each new legal farm shut down a trespass grow? Do we see reduced growing on federal land if we legalize the growing on private land? One would hope so, and it seems a logical conclusion, but not a necessary one. It may be that those who were growing pot illegally (e.g., Mexican cartels) are not going to be suddenly opening up a legitimate shop with appropriate permits and licenses. Illegal grows will remain profitable as farmers can save money by not complying

211 CARRIGAN ET AL., supra note 207, at 4 (citations omitted).

212 David Downs, Huge New Water Fines for Marijuana Farmers in California, SFGATE (June 12, 2015, 9:48 AM), http://blog.sfgate.com/smellthetruth/2015/06/12/ huge-new-water-fines-for-marijuana-farmers-in-california.

213 See Marc Shapp, Tougher Penalties for California's Cannabis Cultivators, NAT'L CANNABIS B. Ass'N (Sept. 4, 2015), http://www.canbar.org/newsworthy/2015/11/4/ tougher-penalties-for-californias-cannabis-cultivators. 
with environmental and land-use laws. More research is needed to assess what our actual tradeoffs might be.

Additionally, we need to look at the land that is now under legal production and ask but for the legalization of marijuana what would be occurring there? Would it have been another crop? If so, which crops? That analysis will help us evaluate whether we think the environmental impacts are increased or reduced. For example, in Palisade, Colorado, marijuana cultivation replaced peach orchards. What are the environmental implications of converting a mature stone fruit orchard to a row crop? In other places, we might see uncultivated land come under cultivation - potentially losing open space or recreational land. Thus, we cannot really assess the true environmental implications of legalization without studies investigating what the tradeoffs really are on a nearly case-by-case basis.

Is there something special about (legal) marijuana cultivation? Do the same reasons we protect agricultural land stretch to protection of all crops? One of the justifications is protection and promotion of an agricultural way of life - a culture of farming. If there is a moral aspect to land conservation, does marijuana make us feel like we are getting our hands dirty? Those opposing the marijuana farm in Palisade, Colorado, argued that growing pot is unethical. Of course, some commenters assert that the most vocal members are peach growers who are selling their fruit to distilleries and the ethical positions are muddy. The folks in Palisade were also upset because it was changing the community landscape. I mean that quite literally, the land is all peach tree orchards and now this plot would be converted to marijuana.

Some fear the impacts of legalization on the environment and local communities without planned growth and development. ${ }^{214}$ Generally, rapid expansion of industries can lead to environmental and land-use problems, and in this context explosion of marijuana cultivation is no different. ${ }^{215}$ Marijuana grows use highly energy-intensive methods to produce ideal conditions and increase yield during cultivation. ${ }^{216}$ Indoor grows specifically demand a great deal of energy for lighting, dehumidification, temperature control, and irrigation. ${ }^{217}$ After California made marijuana available for medical use in 1996,

\footnotetext{
214 See Stoa, supra note 130, at 300.

215 See Campbell \& DiFurio, supra note 8.

216 See Evan Mills, The Carbon Footprint of Indoor Cannabis Production, 46 ENERGY POL'Y 58, 58 (2012).

217 Id. at 59; see Carah et al., supra note 33, at 823; Harkinson, supra note 13.
} 
Humboldt County saw a fifty percent rise in residential electricity use. ${ }^{218}$

This Article examines these conundrums without reaching a conclusion about the legality of the different programs or tax breaks. Instead, I conclude with a word of caution for both landowners and conservation organizations. Until case law or specific statutes and policies address some of these issues, agriculturalists and land trusts should both be cautious about entering into agreements regarding marijuana cultivation. Specifically, I recommend that land trusts avoid any involvement with marijuana cultivation at this time. It simply puts conservation lands at too great of risk. This may mean adding tasks to the annual inspections to ensure that farmers have not switched crops. Land trusts should consider shifting monitoring visits to coincide with the marijuana growing season so they can confirm it is not being produced on protected properties. I encourage land trusts to continue to include provisions within their conservation easements that prohibit conflicts with other laws.

States passed laws regarding marijuana without also thinking about regulations for cultivation. This is unsurprising when many laws came about as the result of voter initiatives. ${ }^{219}$ Even in the wake of legalization, legislation and regulations focused on regulating the business ends of the venture and collecting taxes. ${ }^{220}$ If communities have not done so already, they need to now take the time to consider the environmental and land-use implications of these legal changes.

While marijuana cultivation is a special case, it also highlights a concern generally of trying to determine land-use rules where underlying programs and protection did not contemplate the use at the time of policy or contract formation. Particularly in the case of perpetual protections like conservation easements, users and interpreters of these agreements must carve a path for working with unforeseen land uses. States should explicitly answer the question of whether marijuana will be treated as agriculture or categorized as a farming activity. While communities should retain their zoning authority and ability to keep out marijuana cultivation if they so choose, there are many state-level programs including tax benefits, subsidies, and extension programs that apply to agriculture generally. Even if marijuana is a unique crop, there is no reason why such

218 Mills, supra note 216, at 59.

219 See, e.g., Stoa, supra note 130, at 299 (detailing the example of California's Proposition 215, whose short text provided little guidance to state and local legislatures about the cultivation of marijuana).

220 See id. 
[Vol. 51:1673

programs and benefits should not extend to its cultivation. Without making a moral judgment on the use or cultivation of marijuana, one cannot ignore the fact that it is not the same as growing wheat. Communities should not be silent when states legalize it, but instead should take the opportunity to openly debate their community norms and adopt a policy that reflects their needs and values.221

221 See, e.g., Ifham Nizam, Move to Ban Tobacco Cultivation Questioned, SundaY LEADER, http://www.thesundayleader.lk/2017/06/18/move-to-ban-tobacco-cultivationquestioned (noting that other countries, for example, ban production of tobacco based on environmental impacts, moral objections to tobacco, and impact on health of tobacco farmhands). 